\title{
Review \\ Seaweed-Derived Proteins and Peptides: Promising Marine Bioactives
}

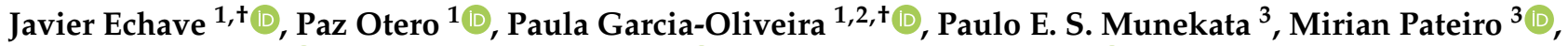 \\ Jose M. Lorenzo $^{3,4} \mathbb{D}^{\mathbb{D}}$, Jesus Simal-Gandara ${ }^{1, * \mathbb{D}}$ and Miguel A. Prieto ${ }^{1,2, * \mathbb{D}}$
}

1 Nutrition and Bromatology Group, Department of Analytical Chemistry and Food Science, Faculty of Food Science, Universidade de Vigo, 32004 Ourense, Spain; javier.echave@uvigo.es (J.E.); paz.otero@uvigo.es (P.O.); paula.garcia.oliveira@uvigo.es (P.G.-O.)

2 Centro de Investigação de Montanha (CIMO), Instituto Politécnico de Bragança, Campus de Santa Apolonia, 5300-253 Bragança, Portugal

3 Centro Tecnológico de la Carne de Galicia, Avd. Galicia No. 4, Parque Tecnológico de Galicia, San Cibrao das Viñas, 32900 Ourense, Spain; paulosichetti@ceteca.net (P.E.S.M.); mirianpateiro@ceteca.net (M.P.); jmlorenzo@ceteca.net (J.M.L.)

4 Área de Tecnología de los Alimentos, Facultad de Ciencias de Ourense, Universidade de Vigo, 32004 Ourense, Spain

* Correspondence: jsimal@uvigo.es (J.S.-G.); mprieto@uvigo.es (M.A.P.)

+ These authors contributed equally to this work.

\section{check for}

updates

Citation: Echave, J.; Otero, P.;

Garcia-Oliveira, P.; Munekata, P.E.S.;

Pateiro, M.; Lorenzo, J.M.;

Simal-Gandara, J.; Prieto, M.A.

Seaweed-Derived Proteins and

Peptides: Promising Marine

Bioactives. Antioxidants 2022, 11, 176.

https://doi.org/10.3390/

antiox11010176

Academic Editors: Raffaella Boggia, Giosuè Costa and Federica Turrini

Received: 29 November 2021

Accepted: 14 January 2022

Published: 17 January 2022

Publisher's Note: MDPI stays neutral with regard to jurisdictional claims in published maps and institutional affiliations.

Copyright: (C) 2022 by the authors. Licensee MDPI, Basel, Switzerland. This article is an open access article distributed under the terms and conditions of the Creative Commons Attribution (CC BY) license (https:// creativecommons.org/licenses/by/ $4.0 /)$.

\begin{abstract}
Seaweeds are a typical food of East-Asian cuisine, to which are alleged several beneficial health effects have been attributed. Their availability and their nutritional and chemical composition have favored the increase in its consumption worldwide, as well as a focus of research due to their bioactive properties. In this regard, seaweed proteins are nutritionally valuable and comprise several specific enzymes, glycoproteins, cell wall-attached proteins, red algae phycobiliproteins, lectins, peptides, or mycosporine-like amino acids. This great extent of molecules has been reported to exert significant antioxidant, antimicrobial, anti-inflammatory, antihypertensive, antidiabetic, or antitumoral properties. Hence, knowledge on algae proteins and derived compounds have gained special interest for the potential nutraceutical, cosmetic or pharmaceutical industries based on these bioactivities. Although several molecular mechanisms of action on how these proteins and peptides exert biological activities have been described, many gaps in knowledge still need to be filled. Updating the current knowledge related to seaweed proteins and peptides is of interest to further asses their potential health benefits. This review addresses the characteristics of seaweed protein and protein-derived molecules, their natural occurrence, their studied bioactive properties, and their described potential mechanisms of action.
\end{abstract}

Keywords: seaweed; protein; peptides; bioactive; molecular mechanisms

\section{Introduction}

Nowadays, the increase in pathologies related to diet such as cardiovascular diseases, obesity, or diabetes is a matter of concern in our society. Because of that, consumers are more interested in healthy natural products that could prevent the appearance of such diseases. In this sense, seaweed consumption is gaining importance in Western countries due to their good nutritional values. In addition, these organisms are a valuable source of bioactive compounds with increasing demand in food, pharmaceutical, and cosmetic applications [1]. In recent years, the protein content of seaweeds has been increasingly highlighted. These organisms contain high levels of essential amino acids (EAAs) and also specific proteins like lectins, glycoproteins (GPs), or phycobiliproteins (PBPs), which have been shown to exert different biological activities.

Table 1 shows the protein content and amino acids (AA) composition of some seaweed species often used as foods or food ingredients. It has been reported that protein content 
varies according to each taxonomic class, being green (Chlorophyceae), brown (Phaeophyceae), or red (Rhodophyceae) seaweeds [2]. According to data, protein concentration is generally higher in red seaweed species (12.5-35.2\%), followed by green (9.6-23.3\%), and brown (4.5-16.8\%) (Table 1). Nonetheless, many red seaweed species have significant protein levels comparable to those found in fish, eggs, cereals, and soybean [3]. Considering this, protein extraction from seaweeds for functional applications can prove feasible [4].

AA composition is an important parameter to determine the nutritional quality of proteins, as higher EAA abundancies contribute to meeting their daily requirements [5]. Seaweed proteins (SPs) tend to contain high amounts of EAA, generally above $30 \%$ of their protein composition [6] but are also described to be above $40 \%$ (Table 1). This EAA abundancy is close to proteins and foods regarded as good sources of EAA, such as casein $(43.6 \%)$, ovalbumin $(52.4 \%)$, or legumes $(\sim 45 \%)$ [7,8]. Considering specific AA, most analyzed seaweeds show Glu and Asp following by Gly and Ala as the major AA [9,10]. In addition, seaweeds are rich in EAA like Val, Leu, Lys, and Phe, which are represented in high proportions from total AA (Table 1). It is noteworthy that monosodium glutamate, derived from Glu and naturally occurring in seaweed, is liable for the umami taste [11], and Gly and Ala are flavor-related amino acids that contribute to the particular taste of seaweeds [12]. Some seaweeds also seem to contain significant levels of Tau, which is a conditionally-EAA required for bile digestion but mainly found in meats [13].

Table 1. Protein content and aminoacidic composition of seaweeds.

\begin{tabular}{|c|c|c|c|c|c|}
\hline Species & $\begin{array}{l}\text { Protein } \\
(\% \mathrm{dw})\end{array}$ & AA Composition (g/100 g Protein) & $\begin{array}{l}\text { Free AA } \\
(\mathrm{mg} / \mathrm{g})\end{array}$ & $\begin{array}{c}\text { EAA } \\
(\% \text { TAA })\end{array}$ & Ref. \\
\hline \multicolumn{6}{|c|}{ Rhodophyceae } \\
\hline \multirow{2}{*}{$\begin{array}{l}\text { Palmaria } \\
\text { palmata }\end{array}$} & 12.5 & $\begin{array}{c}\text { 4.7 Thr, 6.1 Val, 3.6 Iso, 5.9 Leu, 0.5 Tyr, 3.8 Phe, 4.6 His, 5.6 Lys, } 2.7 \\
\text { Met, 4.1 Cya, 3 Tau, 10.2 Asp, 5 Ser, 15.5 Glu, 5.8 Gly, 6.3 Ala, } 2.1 \\
\text { Cys, } 6 \text { Arg, 4.4 Pro. }\end{array}$ & 112.18 & 37.7 & [14] \\
\hline & 16.2 & $\begin{array}{c}\text { 7.6 Ala, 6.8 Arg, 12.5 Asp, 12.3 Glu, 6.5 Gly, 1.6 His, } 4 \text { Ile, } 7 \text { Leu, } 7.7 \\
\text { Lys, 2.2 Met, 5 Phe, 5.5 Pro, 6 Ser, 5.3 Thr, 3.4 Tyr, 6.6 Val }\end{array}$ & 124 & 24.8 & [15] \\
\hline $\begin{array}{l}\text { Porphyra } \\
\text { dioica }\end{array}$ & 28.7 & $\begin{array}{c}\text { 3.3 Asp, 3.1 Glu, } 3 \text { Ala, 2.3 Arg, 1.8 Gly, 1.6 Ser, } 1 \text { Tyr, 0.9 Pro, } 1.1 \\
\text { Phe, 0.6 His, 1.1 Ile, 2.2 Leu, 2.2 Lys, 0.5 Met, 1.2 Thr, 1.2 Val }\end{array}$ & 286.6 & 39.8 & [3] \\
\hline $\begin{array}{l}\text { Porphyra } \\
\text { purpurea }\end{array}$ & 33.2 & $\begin{array}{l}\text { 6.6 Asp, 4.6 Ser, 8.3 Glu, 7.5 Gly, 2.2 His, 9 Arg, 5 Thr, 8 Ala, 3.8 Pro, } \\
\text { 1.3 Met, 0.4 Cys, 4.8 Val, 2.3 Lys, 3.4 Ile, 5.3 Leu, 7.8 Phe, 2.9 Tyr }\end{array}$ & n.a. & 41.0 & [16] \\
\hline $\begin{array}{l}\text { Pyropia } \\
\text { columbina }\end{array}$ & 24.6 & $\begin{array}{c}\text { 12.2 Asp, 10.5 Glu, 6.1 Ser, 1.2 His, 8.8 Gly, 5.9 Thr, 6.1 Arg, } 12.5 \text { Ala, } \\
\text { 3.9 Pro, 2.5 Tyr, 3.7 Phe, 5.8 Val, 1.6 Met, 1.9 Cys, 2.7 Ile, 0.6 Trp, 7.3 } \\
\text { Leu, } 6 \text { Lys }\end{array}$ & n.a. & 35.0 & [10] \\
\hline \multirow{2}{*}{$\begin{array}{l}\text { Chondrus } \\
\text { crispus }\end{array}$} & 35.2 & $\begin{array}{c}\text { 5.5 Thr, 6.2 Val, 4.5 Ile, 6.9 Leu, 2.7 Tyr, 4.3 Phe, 2.1 His, 5.3 Lys, 3.3 } \\
\text { Met, 2.9 Cya, 1.2 Tau, 12 Asp, 5.1 Ser, 12.1 Glu, 5.2 Gly, 7.5 Ala, 0.7 } \\
\text { Cys, 6.5 Arg, 5.6 Pro }\end{array}$ & 226.2 & 40.9 & [14] \\
\hline & 19.5 & $\begin{array}{c}\text { 3.6 Asp, 3.1 Glu, 4.6 Ser, 1.4 Thr, 1.8 His, 0.3 Gln, 0.3 Tau, 2.8 Arg, 0.4 } \\
\text { Ala, 1.4 Tyr, 3.4 Lys, 2 Val, 0.2 Met, 1.5 Phe, 1.6 Ile, 2 Leu, 1.5 Hyp }\end{array}$ & 72.8 & 46.7 & [17] \\
\hline \multirow{2}{*}{$\begin{array}{l}\text { Osmundea } \\
\text { pinnatifida }\end{array}$} & 24.3 & $\begin{array}{l}\text { 4.8 Asp, 4.5 Glu, 3.9 Ser, 2.7 Thr, 3.7 His, 0.3 Gly, 0.1 Gln, 0.4 Tau, 2.4 Arg, } \\
\text { 1.1 Ala, 1.7 Tyr, 3 Lys, 2.6 Val, 0.5 Met, 1.5 Phe, 2.1 Ile, 2.5 Leu, } 1 \text { Hyp }\end{array}$ & 66.9 & 47.9 & [17] \\
\hline & 20.7 & $\begin{array}{l}\text { 13.6 Asp, 12.1 Glu, 2.7 Ser, 2.5 Gly, 0.9 His, 3.7 Arg, 5.7, Thr, 0.7 Ala, } \\
\text { 15.8 Pro, 2 Tyr, 2.2 Val, 1.9 Met, 16.5 Ile, 2.2 Phe, 2.7 Lys }\end{array}$ & n.a. & 41.6 & [7] \\
\hline $\begin{array}{l}\text { Gracilaria } \\
\text { chilensis }\end{array}$ & 13.7 & $\begin{array}{l}\text { 1.1 Asp, 1.5 Glu, 0.7 Ser, 1.1 His, 0.4 Gly, 0.6 Thr, 0.6 Arg, 0.6 Ala, 0.3 } \\
\text { Tyr, 0.7 Val, 1.8 Met, 0.7 Cys, 0.8 Ile, 0.4 Leu, 1 Phe, 0.6 Lys }\end{array}$ & n.a. & 42.8 & [18] \\
\hline $\begin{array}{l}\text { Gracilaria } \\
\text { gracilis }\end{array}$ & 18.7 & $\begin{array}{l}\text { 1.4 Arg, 0.1 His, 1.3 Lys, } 1 \text { Thr, 0.9 Ile, 1.2 Leu, } 1 \text { Val, 0.3 Met, } 0.9 \\
\text { Phe, 0.9 Pro, 1.2 Ala, 0.6 Tyr, 2.1 Asp, 2.5 Glu, 1.3 Gly, 1.2 Ser }\end{array}$ & n.a. & 45.6 & [19] \\
\hline $\begin{array}{l}\text { Gelidium } \\
\text { corneum }\end{array}$ & 21 & $\begin{array}{l}\text { 1.9 Ala, 0.8 Gly, 1.4 Val, 1.6 Leu, 0.9 Ile, 0.7 Thr, 0.8 Ser, } 1.5 \text { Pro, } 2 \\
\text { Asp, 0.1 Met, 1.6 Glu, 1 Phe, 1.2 Lys, 0.3 His, 0.7 Tyr }\end{array}$ & n.a. & 44.1 & [20] \\
\hline
\end{tabular}


Table 1. Cont.

\begin{tabular}{|c|c|c|c|c|c|}
\hline Species & $\begin{array}{l}\text { Protein } \\
(\% \mathrm{dw})\end{array}$ & AA Composition (g/100 g Protein) & $\begin{array}{c}\text { Free AA } \\
(\mathrm{mg} / \mathrm{g})\end{array}$ & $\begin{array}{c}\text { EAA } \\
(\% \text { TAA })\end{array}$ & Ref. \\
\hline \multicolumn{6}{|c|}{ Rhodophyceae } \\
\hline \multicolumn{6}{|c|}{ Phaeophyceae } \\
\hline $\begin{array}{l}\text { Sargasum } \\
\text { maclurei }\end{array}$ & 8.4 & $\begin{array}{c}\text { 3.6 Thr, 6.2 Leu, 3.7 Ile, 4 Phe, 4.1 Lys, 1.3 Met, 2.1 Tyr, 2.3 Trp, 8.2 } \\
\text { Asp, 29.7 Glu, 3.5 Cys, 1.3 His, 4.2 Gly, 3.9 Pro, 7.9 Ala, 3.8 Arg }\end{array}$ & 74.9 & 27.8 & [21] \\
\hline $\begin{array}{l}\text { Fucus } \\
\text { vesiculosus }\end{array}$ & 12.9 & $\begin{array}{l}\text { 6.1 Thr, 5.8 Val, 2.1 Met, 5 Ile, 8.6 Leu, 5.4 Phe, 8 Lys, 1.9 His, 5.5 Arg, } \\
\text { 3.2 Tyr, 16.7 Asn, 6.3 Ser, 19.7 Glu, 6.5 Gly, 9.8 Ala, 5.7 Pro, 2 Cys }\end{array}$ & 119 & 40.9 & [22] \\
\hline \multirow{2}{*}{$\begin{array}{l}\text { Fucus } \\
\text { spiralis }\end{array}$} & 11.8 & $\begin{array}{l}\text { 5.2 Arg, 7.2 Glu, 5.5 Ser, 2.7 Thr, 1.6 His, 0.1 Gln, 0.7 Tau, 1.5 Arg, } \\
\text { 0.7 Ala, 3.7 Lys, 2.2 Val, 0.2 Met, 0,1 Trp, 1.2 Phe, 1,9 Ile, 1.8 Hyp }\end{array}$ & 130 & 38.7 & [17] \\
\hline & 9.7 & $\begin{array}{l}\text { 5.6 Asp, 12.1 Glu, 11.4 Ser, 7.4 Gly, 3.2 His, 11.7 Arg, 10.8 Thr, } 4 \text { Ala, } \\
\text { 6.9 Pro, 7.7 Tyr, 11.4 Val, 6.3 Met, 15.4 Leu, 15.3 Ile, 9.8 Phe, 12.5 Lys }\end{array}$ & n.a. & 63.5 & {$[7]$} \\
\hline \multirow{2}{*}{$\begin{array}{l}\text { Ascophylum } \\
\text { nodosum }\end{array}$} & 4.5 & $\begin{array}{l}\text { 6.9 Ala, 4.4 Arg, 16 Asp, 16.3 Glu, 5.9 Gly, 1.4 His, 4.4 Ile, 7.5 Leu, } \\
\text { 5.5 Lys, 2 Met, 5.3 Phe, 4.5 Pro, 5.4 Ser, 5.8 Thr, 2.9 Tyr, 6 Val }\end{array}$ & 35 & 29.2 & [15] \\
\hline & 9.4 & $\begin{array}{l}\text { 4.1 Asp, 7.2 Glu, 3.9 Ser, 1.9 Thr, 1.1 His, 0.7 Tau, 1.7 Arg, 1.5 Ala, 0.9 } \\
\text { Tyr, 3.3 Lys, 1.9 Val, 0.4 Met, 0.1 Trp, 1.2 Phe, 1.6 Ile, 2.3 Leu, 1.6 Hyp }\end{array}$ & 133 & 39.2 & [17] \\
\hline $\begin{array}{l}\text { Saccharina } \\
\text { latissima }\end{array}$ & 12 & $\begin{array}{l}\text { 11 Ala, 4.8 Arg, 13.4 Asp, 13.8 Glu, 5.6 Gly, 1.6 His, 4.4 Ile, 7.9 Leu, } \\
\text { 5.9 Lys, 2.4 Met, 5.2 Phe, 4.5 Pro, 5 Ser, 5.3 Thr, 3.1 Tyr, 6 Val }\end{array}$ & 98 & 32.7 & [15] \\
\hline $\begin{array}{l}\text { Bifurcaria } \\
\text { bifurcata }\end{array}$ & 8.9 & $\begin{array}{c}\text { 3.6 Thr, 3.7 Val, 1.7 Met, 2.9 Iso, 5.2 Leu, 3.3 Phe, 3.9 Lys, 1.3 His, 3.3 } \\
\text { Arg, 1.7 Tyr, 8 Asn, 3.5 Ser, 15 Glu, 3.9 Gly, 8.4 Ala, 3.1 Pro }\end{array}$ & 73.2 & 39.9 & [22] \\
\hline \multirow{2}{*}{$\begin{array}{l}\text { Undaria } \\
\text { pinnatifida }\end{array}$} & 16.5 & $\begin{array}{l}\text { 4.3 Asp, 7.6 Glu, 5.8 Ser, 2.4 Thr, 1.4 His, 0.2 Gly, 0.6 Tau, 2.7 Arg, } 3.4 \\
\text { Ala, 1.5 Tyr, 2.8 Lys, 2.5 Val, 0.7 Met, 1.7 Phe, 2 Ile, 3 Leu, 0.9 Hyp }\end{array}$ & 64.7 & 37.2 & [17] \\
\hline & 16.8 & $\begin{array}{l}\text { 7.5 Asp, 4.1 Ser, } 12 \text { Glu, 6.5 Gly, 1.7 His, 8.8 Arg, 2.9 Thr, 9.7 Ala, } 4.4 \\
\text { Pro, 0.1 Met, 0.3 Cys, 5.8 Val, 3.9 Lys, 5 Ile, 8.6 Leu, 4.8 Phe, } 2 \text { Tyr }\end{array}$ & n.a. & 23.4 & [16] \\
\hline
\end{tabular}

\section{Chlorophyceae}

6.1 Asp, 5.2 Glu, 7.8 Ser, 2 Thr, 3.3 His, 0.2 Gly, 0.2 Gln, 0.3 Tau,

Ulva spp. 23.3 3.7Arg, $1.1 \mathrm{Ala}, 1.9 \mathrm{Tyr}, 3.2 \mathrm{Lys}, 3.5$ Val, $0.6 \mathrm{Met}, 0.1$ Trp, 2.4 Phe, 2.6 Ile, 3.5 Leu, $1.4 \mathrm{Hyp}$

\begin{tabular}{|c|c|c|c|c|c|}
\hline \multirow{2}{*}{ Ulva rigida } & 17.4 & $\begin{array}{l}\text { 3.1 Ile, 5.2 Leu, 3.7 Lys, 1.5 Met, 1.1 Cys, 3.3 Phe, 2.2 Tyr, } 5 \text { Thr, 5.6 } \\
\text { Val, 1.4 His, 13 Asp, 9.4 Glu, 4.3 Pro, 6.1 Ser, 7.8 Gly, 12.3 Ala, 4.6 Arg }\end{array}$ & n.a. & 30.8 & [9] \\
\hline & 9.6 & $\begin{array}{l}\text { 12.5 Asp, 9.4, 8.4 Ala, } 6 \text { Arg,6 Gly, 5.5 Ser, 3.2 Tyr, 4.4 Pro, } 1 \text { Hyp, } 5.7 \\
\text { Phe, 2.9 His, 4.4 Ile, 7.8 Leu, 4.7 Lys, 1.3 Met, 4.8 Thr, o.4 Trp, 6.8 Val }\end{array}$ & 4.9 & 40.8 & [3] \\
\hline \multirow{2}{*}{ Ulva lactuca } & 16.4 & $\begin{array}{l}\text { 3.7 Ile, 6.7 Leu, 4.2 Lys, 1.6 Met, 0.4 Cys, 4 Phe, 2.1 Tyr, 4.7 Thr, 6.2 Val, } \\
\text { 1.8 His, 12.3 Asp, 9 Glu, 5.3 Pro, 5.9 Ser, 10.7 Gly, 14.2 Ala, 3.6 Arg }\end{array}$ & n.a. & 33.6 & [9] \\
\hline & 15 & $\begin{array}{l}\text { 8.4 Ala, 6.4 Arg, 12.1 Asp, 13.5 Glu, 6.4 Gly, 1.8, His, 4.2 Ile, } 8 \text { Leu, } \\
\text { 5.5 Lys, 2.2 Met, 5.6 Phe, 4.7 Pro, 5.5 Ser, 5.5 Thr, 3.5 Tyr, 6.4 Val }\end{array}$ & 106.1 & 36.9 & [15] \\
\hline $\begin{array}{l}\text { Ulva } \\
\text { capensis }\end{array}$ & 17.3 & $\begin{array}{l}\text { 3.5 Ile, 6-8 Leu, 3.7 Lys, 1.5 Met, } 4 \text { Phe, } 2 \text { Tyr, 5 Thr, 6.3 Val, 1.7 His, } \\
\text { 17.2 Asp, 10.9 Glu, 3.6 Pro, 6.4 Ser, 8.8 Gly, 11.8 Ala, 3.3 Arg }\end{array}$ & n.a. & 32.7 & [9] \\
\hline Codium fragile & 10.8 & $\begin{array}{l}\text { 0.8 Asp, } 1 \text { Glu, 0.5 Ser, 0.09 His, 0.5 Gly, 0.5 Thr, 0.4 Arg, 0.6 Ala, 0.3 } \\
\text { Tyr, 1.4 Val, 0.9 Met, 0.1 Cys, 0.4 Ile, 0.7 Leu, 0.4 Phe, 0.5 Lys }\end{array}$ & n.a. & 44.7 & [18] \\
\hline $\begin{array}{l}\text { Cladophora } \\
\text { rupestris }\end{array}$ & 12 & $\begin{array}{l}\text { 5.5 Ala, 6.5 Arg, 15.3 Asp, 15.3 Glu, 6.7 Gly, 1.4 His, 3.6 Ile, 7 Leu, } \\
\text { 7.4 Lys, 1.8 Met, 4.5 Phe, 5.7 Pro, 4.3 Ser, 5.1 Thr, 4.3 Tyr, 5.8 Val }\end{array}$ & 95.9 & 38.1 & [15] \\
\hline
\end{tabular}

Notes and Abbreviations. AA: amino acids; EAA: Essential amino acids; TAA: Total amino acids; n.a.: Not analyzed. Amino acids: alanine (Ala); aspartic acid (Asp); arginine (Arg); asparagine (Asn); glutamic acid (Glu); glutamine (Gln); glycine (Gly); hydroxyproline (Hyp); histidine (His); isoleucine (Ile); leucine (Leu); lysine (Lys); methionine (Met); phenylalanine (Phe); proline (Pro); serine (Ser); taurine (Tau); tryptophan (Trp); tyrosine (Tyr); threonine (Thr); valine (Val).

Besides their value from a nutritional point of view, other SPs such as lectins, GPs, or PBPs have been reported to possess specific and relevant biological properties [23]. Mycosporine-like amino acids (MAAs) are other relevant aminic compounds in seaweeds 
account for similar biological properties. According to scientific literature, some of the bioactivities described for SP include antioxidant [24], anti-microbial and antiviral [25], antihypertensive [26], anti-inflammatory [27], anticancer, antithrombotic, and immunomodulatory properties [28]. All these effects depend on: (1) the chemical structure of the compounds, which differs among algae species, (2) parameters affecting seaweed biomass like season and location of collection (in general, the highest protein content in algae occur during the period between winter and early spring and the lowest from summer to early autumn), and (3) chemical alterations of the proteins during extraction and purification processes $[15,17,28]$. Furthermore, following a similar trend observed in other protein hydrolysates such as milk, ovalbumin, or soy hydrolysates, SP hydrolysates appear to contain derived bioactive peptides (BAPs) with a wide range of biological properties [29]. The development of these hydrolysates represents a challenge for scientists trying to identify the link between the chemical structure of peptides and their biological activities. However, numerous reports have evidenced their effective bioactive properties in vitro and in vivo. Indeed, in Japan, Undaria pinnatifida (wakame) and Neopyropia yezoensis (nori) digests have been approved as "foods for specified health uses" under claims of being hypotensive. Some of these products that include seaweed BAPs from these species are Wakame peptide jelly (Riken Vitamin Co., Ltd., Tokyo, Japan) or Nori peptide S (Shirako Co., Ltd., Tokyo, Japan) [30,31].

This work discusses the value and bioactive properties of SPs and derived BAPs. Their reported bioactive properties are highlighted with a special focus on described molecular mechanisms. Potential applications according to their specific bioactivities are explored, as well.

\section{Seaweed Proteins and Derived Peptides}

\subsection{Glycoproteins}

These compounds are proteins covalently linked to various oligosaccharide chains (glycans). Two major types of sugar chains are found in GPs, those bounded by N-glycosyl linkages or by O-glycosyl linkages [32]. GPs are located on the cell wall, on the surface of the cell, or free after secretion, and their roles include intercellular interactions and recognition [33]. Proportions of proteins and sugars of GPs differ from different algae species. For example, Ulva sp. GPs-rich fractions showed a protein proportion up to $33.4 \%$ [34], while in Codium decorticatum, which has GPs of molecular weight (MW) around $48 \mathrm{kDa}$, the protein proportion reached 60\% [35]. Regarding the composition of the prosthetic fraction, seaweed GPs seem to mainly contain mannose [33]. Many seaweed GPs remain to be described, but other potential roles have been explored for bioactive properties in recent works, as shown in Section 3.

\subsection{Lectins}

Lectins are GPs that bind with high specificity to certain mono- or oligosaccharides. Seaweeds are good sources of novel lectins of low MW, especially red seaweeds [36]. The functions of lectins include gamete recognition and reproductive cell fusion, as well as defense against pathogens [36,37]. Lectins can be classified into four main groups: chitin-binding lectins, legume lectins, type-2 ribosome-inactivating proteins, and mannosebinding lectins [38]. In the case of seaweeds, the great majority of these proteins are mannose-binding, which are the major type of glycans found in them [33]. Likewise, relevant seaweed lectins are mannose-specific lectins, which show high binding affinity with these residues [39]. This property allows them to "agglutinate" particles containing these residues, as is the case of bacterial, viral, or eukaryote cell surface GPs [40]. One example is griffithsin, obtained from red Griffithsia sp. seaweeds, which has been described with diverse biological properties (Section 3) [41]. Due to these pharmacological properties, their characterization and isolation are a focus of research in medicine, molecular biology, or biochemistry. However, despite advances in the chemical characterization of seaweed 
lectins, additional information is still needed for a deeper understanding of their molecular structures, binding affinities, and possible biological functions for further applications [42].

\subsection{Phycobiliproteins}

PBPs are hydrosoluble chromophore proteins mainly present in cyanobacteria but also in red seaweeds. Their primary metabolic role is to act as light absorbents during photosynthesis [43]. PBPs include four classes of pigments: blue colored phycocyanin with absorption maxima $\left(\lambda_{\max }\right)$ in the range between 610 and $620 \mathrm{~nm}$, magenta-colored phycoerythrocyanin $\left(\lambda_{\max }: 575 \mathrm{~nm}\right)$, bluish-green-colored allophycocyanin $\left(\lambda_{\max }: 652 \mathrm{~nm}\right)$, and deep red- or pink-colored phycoerythrin (PE) with $\lambda_{\max }$ between 540 and $570 \mathrm{~nm}$ [43]. The major PBP in red seaweeds is PE, of which phycoerythrobilin is its main prosthetic group (Figure 1) [44].

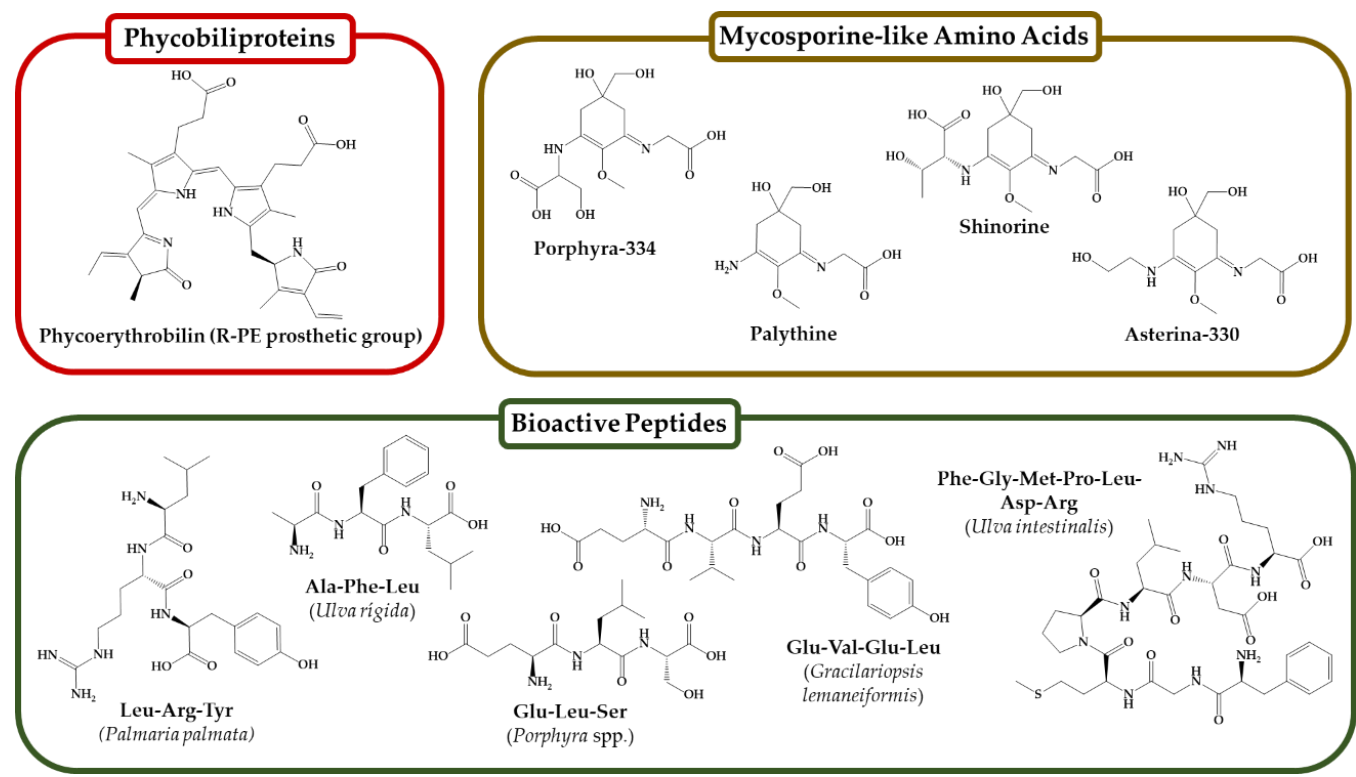

Figure 1. Chemical structure of the chromophore group of R-phycoerythrin, some relevant mycosporine-like amino acids, and bioactive peptides isolated from seaweed protein hydrolysates. Peptide sequences and source are presented in Table 3.

PBPs are used as natural pigments in food, replacing synthetic dyes, or as fluorescent probes in research [45]. Despite this, they are being studied for the development of nutraceuticals due to their bioactivities such as anti-viral, anti-cancer, antioxidant, and anti-inflammatory [46]. For this reason, current research on these molecules lies in function and biosynthesis mechanisms, structure elucidations, and potential applications. Isolation of PBPs has been reported in many species, for instance, Neoporphyra haitanensis [45], Kappaphycus alvarezii [47], Centroceras clavulatum [43], or N. yezoensis [47].

\subsection{Mycosporine-Like Amino Acids}

MAAs are small aminic secondary metabolites of MW below 400 Da (Figure 1) with strong absorption of ultraviolet (UV) radiation, typically between 320 and $360 \mathrm{~nm}$. Thus, MAAs are useful molecules to protect cells from oxidative processes and solar UV-induced damage [48]. Up to now, more than 20 MAAs have been characterized in seaweeds and microalgae. From these, palaythine, asterina, shinorine, porphyra-334, mycosporineglycine, usujirene, or palythene are most common in seaweeds [48]. They are naturally synthesized by various marine organisms, but seaweeds and microalgae are rich sources of them. However, they are much more abundant in red seaweeds, and only a small fraction of brown or green seaweeds presenting them [49]. For instance, porphyra-334 or shinorine are the most common in green or brown seaweeds such as Ulva intestinalis or Alaria esculenta, 
but red species like Pyropia columbina or C. crispus may additionally contain palythene much higher levels of mycosporine-glycine [49].

\subsection{Protein-Derived Hydrolysates and Peptides}

Peptides are protein fragments containing 2 to $40 \mathrm{AA}$ in length generated from proteins by gastrointestinal digestion or from other hydrolyzation processes [50]. The importance of these molecules lies with the fact that some AA sequences, which are not active in SPs, show different biological properties after being released from the protein structure [51]. The development of algal peptides concentrates a blooming sector due to the diverse physiological activities of these molecules. Briefly, after the extraction and isolation of SPs, the main strategy to obtain BAPs from them involves their hydrolyzation (Figure 2). This may be performed by thermal, chemical, or enzymatic degradation, being the latter more extensively used since it allows more homogeneous and consistent patterns of hydrolyzation [23]. Thus, SP hydrolyzation using proteases can be used to maximize the yield of desired BAPs [23]. The process to describe the potential bioactive peptides requires testing different proteases in a single seaweed species [52-54], characterizing the BAP yield [55-57], optimizing the hydrolysis procedure [58], and exploring the effect of sequential hydrolysis using different proteases with defined conditions [59]. As hydrolyzation patterns and BAPs yielded are described, these approaches to define generated peptides allow covering a greater extent of potential bioactivities, as well as efficiency and effectiveness of extraction. Successful production of BPAs from hydrolyzed proteins of Porphyra spp, Palmaria palmata, Ulva spp, among others, have been reported [60-62].

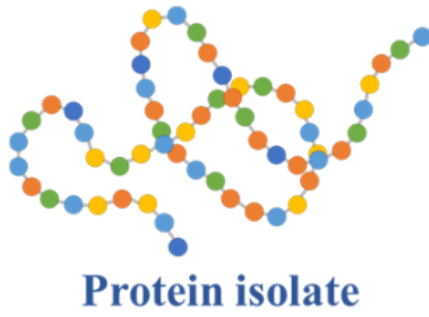

Protein isolate
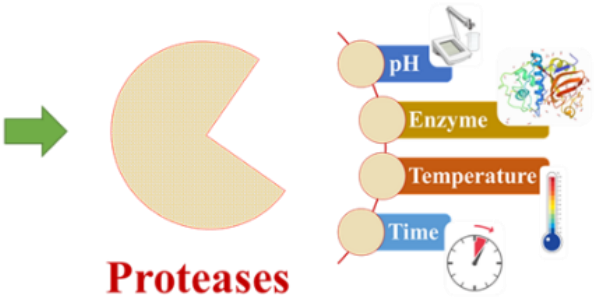

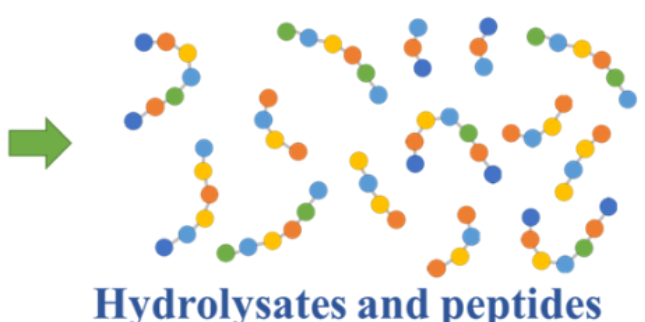

Figure 2. Schematic representation of seaweed protein hydrolysis into peptides. The hydrolyzation process usually involves the action of proteases and the adjustment of reaction parameters. Among the peptides produced by protein hydrolyzation, some display bioactive properties.

\section{Bioactive Properties and Mechanisms of Action}

As described, a wide number of bioactive properties have been reported for SPs, derived hydrolysates, and peptides. However, as their study is still recent, many species and synthesized hydrolysates are yet to be further studied, as well as their possible mechanisms of action. As they are accounted for higher protein content, red algae have been the focus of research in this matter, making them more represented in literature than other groups. Nevertheless, some studies detail or elucidate these mechanisms based on their results. Figure 3 depicts a summary of the described mechanisms of action reported for SPs, BAPs, and MAAs.

\subsection{Antioxidants}

Oxidative stress is considered the major cause liable for a number of hazardous effects on health, such as inflammation, cell death, or unregulated cell proliferation, which in turn, may result in many ailments and diseases such as chronic inflammation, metabolic disorders, or ultimately, cancer [63]. It is mainly caused by the interaction of overabundant reactive oxygen species (ROS) with cell components such as membrane lipids, proteins, or DNA, among others, which leads to the disruption of normal cell metabolism. The ability of antioxidants to "quench" these ROS and avoid potential cell damage ameliorates these hazardous effects [64]. This property is intrinsically related to the chemical structure of 
antioxidants. In the case of SP and BAPs, their antioxidant activity may be related to their amino acid composition and conformation [40].

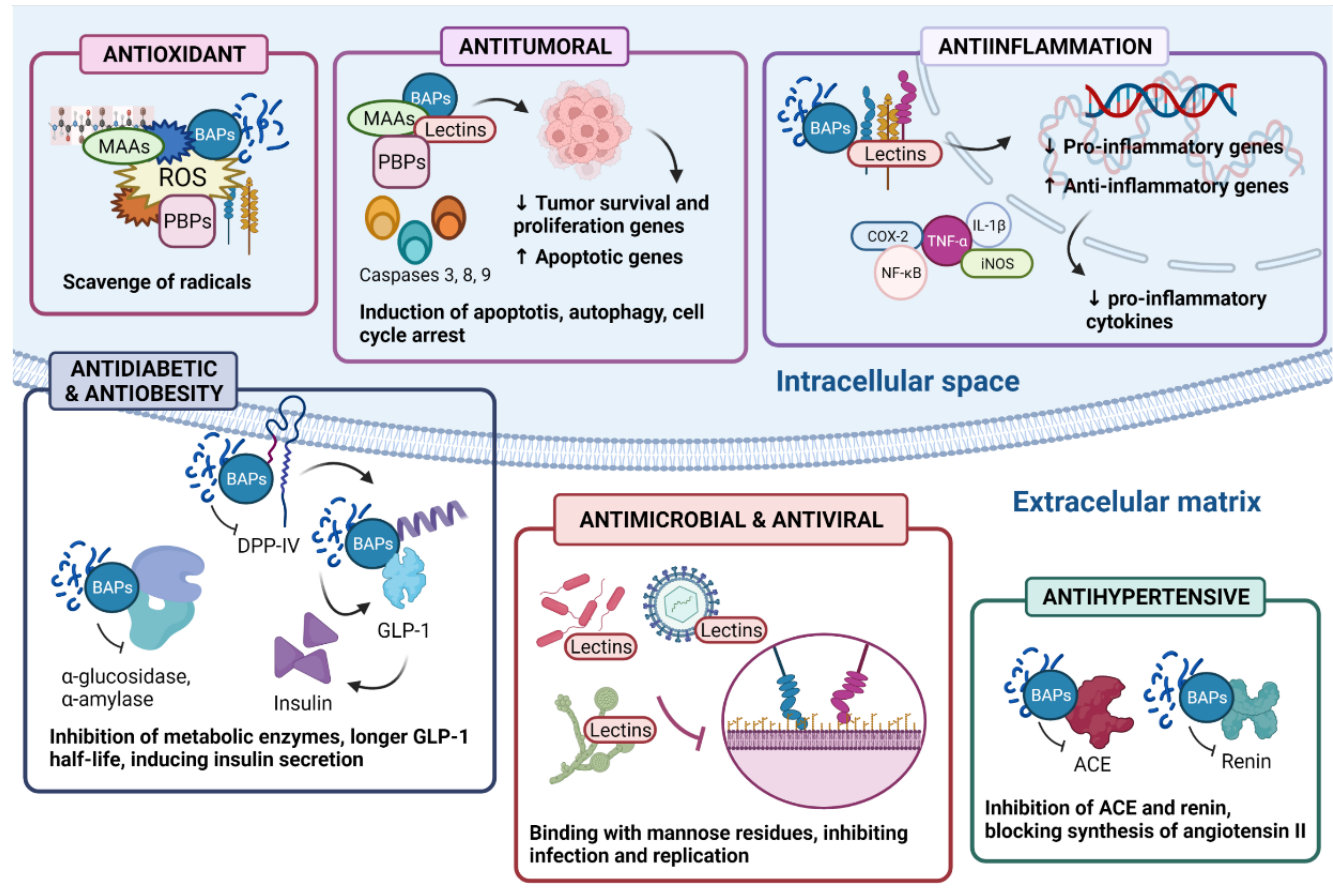

Figure 3. Summary of reported mechanisms of action of several SPs and BAPs. Their location with respect to the bilayer membrane represents that these effects are inducted inside, outside the cell, or on the cell surface. Abbreviations: PBPs: phycobiliproteins; MAAs: mycosporine-like amino acids; BAPs: bioactive peptides; ROS: reactive oxygen species; IL-1 $\beta$ : interleukin- $1 \beta$; TNF- $\alpha$ : tumor necrosis factor- $\alpha$; COX-2: cyclooxygenase-2; iNOS: inducible nitric oxide synthase; NF- $\mathrm{BB}$ : nuclear factor- $\mathrm{kB}$; DPP-IV: dipeptidyl peptidase-IV; GLP-1: glucagon-like peptide-1; ACE: angiotensin I-converter enzyme.

Several studies have corroborated the antioxidant properties of SPs. For example, the antioxidant activity of a purified GP from $C$. decorticatum was assessed based on the ability to scavenge 2,2-diphenyl-1-picrylhydrazyl (DPPH), hydroxyl, superoxide, and nitric oxide radicals. According to the results, the GP showed positive results in a dosedependent manner, which was attributed to the presence of aromatic amino acid present in its chemical structure $[35,65]$. A thyroglobulin-binding lectin from Sargassum fusiforme inhibited up to $80 \%$ of DPPH radicals and $60 \%$ of 2,2' -azino-bis(3-ethylbenzothiazoline-6sulfonic acid) (ABTS) radicals. Authors considered that these results were due to its glycan and aminoacidic composition, rich in G, T, and A [40]. Regarding MAAs, these compounds have been long-known to be effective antioxidants, especially against UV-light induced oxidation [66]. A recent and extensive study evaluated the antioxidant activity of a wide number of MAAs isolated from G. domingensis, such as asterina-330, shinorine, palythine, or palythinol [24]. Among the isolated MAAs, asterina-330 showed by far the most significant antioxidant activity with $10.03 \mu \mathrm{mol}$ Trolox equivalents/mol of the compound, in contrast with the $2953 \mu \mathrm{mol}$ Trolox equivalents / mol of the compound obtained for gallic acid after $1 \mathrm{~h}$ of ABTS assay.

Numerous studies have successfully produced BAPs with antioxidant properties for different seaweed species. According to data, it has been suggested that BAPs display higher antioxidant activity than SPs or SP hydrolysates of higher MW. This could be due to the enhanced cell and chemical accessibility of released amino acids from proteins. For example, fractionation of P. palmata chymotrypsin-produced BAPs based on their MW showed that those fractions with lower ones displayed higher antioxidant activities. The fraction containing peptides $<10 \mathrm{kDa}$ displayed the most significant antioxidant properties 
following a DPPH assay [55]. In another study conducted with the same species, the authors obtained a peptide SDIAPGGNM, which showed an oxygen radical absorbance capacity (ORAC) of $152 \mathrm{nmol} \mathrm{TE} / \mu \mathrm{mol}$ peptide and a ferric reducing antioxidant power (FRAP) of $21 \mathrm{nmol} \mathrm{TE} / \mu \mathrm{mol}$ peptide [67]. Other seaweeds have also been reported to be a source of BAPs. For example, proteins from $P$. haitanensis were digested using pepsin, and their antioxidant properties were evaluated in vitro by 2,2-diphenyl-1-picrylhydrazyl (DPPH) assay and ferric reducing antioxidant power (FRAP), showing positive results [68]. Pepsin and pepsin-Corolase ${ }^{\circledR}$ hydrolyzed biomass from $P$. dioica resulted in a diverse BAP pattern, of which the pepsin fraction displayed significantly higher antioxidant activity on various antioxidant assays. Yet both treatments resulted in an increase in antioxidant activity, which was related to the release of $>10 \mathrm{kDa}$ peptides [69]. In another study by the same authors, $P$. dioica biomass and its protein isolate were hydrolyzed using the proteases Prolyve ${ }^{\circledR}$ and Flavourzyme ${ }^{\circledR}$. This digestion achieved a 5-fold increase in antioxidant activity. The authors noted that phenolic compounds were also released after enzymatic digestion, which paired with a positive correlation with protein degradation, suggesting a synergistic dynamic between these elements [70]. Finally, a recent study characterized the optimum hydrolysis conditions of G. lemaneiformis proteins with chymotrypsin [58]. The variables considered in this experiment were enzyme/substrate ratio (1-3\%), temperature (41-19 $\left.{ }^{\circ} \mathrm{C}\right)$, and $\mathrm{pH}(8.5-9.5)$, whereas substrate concentration and reaction time were kept constant $(10 \mathrm{mg} / \mathrm{mL}$ and $2.0 \mathrm{~h}$, respectively). According to the authors, the optimum conditions to improve the extraction of antioxidant peptides were enzyme/substrate ratio (1:10), $46.4^{\circ} \mathrm{C}$, and $\mathrm{pH}$ 9.2. After separation and purification steps, GLWKTF was identified as the principal antioxidant, whose properties were attributed to its small molecular size and the presence of hydrophobic and/or aromatic amino acids [58].

\subsection{Antimicrobials and Antivirals}

Among SPs, lectins have been reported in recent years to be potent and effective antibacterial and antiviral agents due to their binding with monosaccharide residues of cell walls or membrane of yeasts, bacteria, and viruses [25,36]. Specifically, different mannosebinding lectins have been isolated from seaweeds, which have potent antiviral properties, as many viruses present mannose residues in their capsid or envelope [36]. For example, two recently isolated lectins from the green alga $C$. isthmocladum with galactose-binding activity were found to inhibit biofilm formation of Staphylococcus aureus and S. epidermidis up to $60 \%$, compared to the control samples (Table 2). However, they did not display any significant antibacterial or antibiofilm activity against Escherichia coli [71]. The mannosebinding lectin griffithsin, derived from the red macroalga genus Griffithsia sp., has become a main focus of research since it was isolated in 2004 [72]. Griffithsin has been thoroughly studied for its potential applications against human and cattle viral infections, showing promising results against human immunodeficiency virus (HIV), human herpes virus (HSV), hepatitis C or severe acute respiratory syndrome-coronavirus (SARS-CoV), among others, both in vitro and in vivo $[73,74]$. Indeed, recent work has demonstrated that the synergistic cutaneous application of carrageenan and griffithsin inhibited simian-HIV in rhesus macaques, as well as HSV and HPV in mice [75]. The broad action range of griffithsin against viruses with diverse structural features has made it to be proposed as an antiviral agent against SARS-CoV-2, as it can effectively bind to the Spike surface GPs of SARS-CoV, inhibiting cell-to-cell infection [76]. It has also been shown to have a prolonged half-life, both by oral and parenteral administration, which supports its potential application in antiviral treatment [77]. Grifonin-1, a griffithsin-derived peptide, has also shown significant inhibition of HIV infection in in vitro cultures, along with a very low cytotoxicity index [78]. In addition, a mannose-binding lectin recently isolated from Grateulopia chiangii showed significant inhibition against various strains of influenza, like H1N1, and towards HSV1 and HSV2 (Table 2) [79]. Nevertheless, it did not show antiviral activity against HIV, indicating that although broad, the action range of these lectins is dependent on their binding site affinities. 
Apart from lectins, to our knowledge, there are few reports on antimicrobial activity from other SP and BAPs. For example, a study assessed the antifungal properties of PBPs from Hydropuntia cornea against the common rotting fungi, Botrytis cinerea, assessing its potential growth inhibition when applied to tomatoes. With a concentration of 0.3 $\mathrm{mg} / \mathrm{mL}$, PBPs successfully inhibited fungal growth and spore germination by $33 \%$ and $80 \%$, respectively [80]. According to the literature, it could be suggested that other proteinderived components could act as antimicrobial agents, but especially in combination with other seaweed components like phenolics and sulfated polysaccharides. In the study of Beaulieu et al., a hydrolysate from S. longicruris was obtained using trypsin, and antimicrobial properties were tested. The hydrolysate inhibited up to $40 \%$ of the growth inhibition on S. aureus. However, when individual peptides were isolated, no antimicrobial activity was observed. Authors proposed that this could be due to the co-extraction of sulfated polysaccharides, which are indeed accounted for antimicrobial properties [81].

Table 2. Reported bioactive proteins from seaweeds and their mechanisms of action.

\begin{tabular}{|c|c|c|c|c|}
\hline Species & Protein(s) & Bioactivity & Mechanism of Action & Ref. \\
\hline \multicolumn{5}{|c|}{ Rhodophyceae } \\
\hline \multirow{3}{*}{ Griffithsia sp. } & \multirow{3}{*}{$\begin{array}{l}\text { Lectin } \\
\text { (Griffithsin) }\end{array}$} & In vivo, antiviral & $\begin{array}{l}\text { Mannose-binding lectin binds with viral envelope GPs, } \\
\text { inhibiting viral infection of HIV-1, HSV, and HPV }\end{array}$ & [75] \\
\hline & & In vitro, antiviral & $\begin{array}{l}\text { Mannose-binding lectin binds with Spike GPs, } \\
\text { inhibiting viral infection of SARS-CoV }\end{array}$ & [82] \\
\hline & & In vitro, antiviral & $\begin{array}{l}\text { Griffithsin and synthetic polymers showed high } \\
\text { virucidal activity in cell-associated HIV-1 and in the } \\
\text { presence of seminal and vaginal simulants. Blocking of } \\
\text { CD4+ viral binding }\end{array}$ & [83] \\
\hline $\begin{array}{l}\text { Grateloupia } \\
\text { chiangii }\end{array}$ & Lectin & In vitro, antiviral & $\begin{array}{l}\text { Mannose-binding lectin binds with viral envelope GPs, } \\
\text { inhibiting viral infection of Influenza H1N1 and } \\
\text { HSV1/2 }\end{array}$ & [79] \\
\hline $\begin{array}{l}\text { Kappaphyrus } \\
\text { alvarezii }\end{array}$ & Lectin & In vitro, antiviral & $\begin{array}{l}\text { Mannose-binding lectin binds to Influenza } \\
\text { hemagglutinin and HIV GP gp120, avoiding infection }\end{array}$ & [84] \\
\hline $\begin{array}{l}\text { Kappaphycus } \\
\text { striatum }\end{array}$ & Lectin & $\begin{array}{l}\text { In vitro, } \\
\text { antimicrobial }\end{array}$ & $\begin{array}{c}\text { Growth inhibition of Vibrio alginolyticus }(25.4 \mu \mathrm{g} / \mathrm{mL}) \\
\text { and Enterococcus cloacae }(101.6 \mu \mathrm{g} / \mathrm{mL}) \text {. Did not inhibit } \\
\text { other Vibrio spp., Staphylococcus aureus, or } \\
\text { Escherichia coli }\end{array}$ & [85] \\
\hline Gracilaria fisheri & Lectin & $\begin{array}{l}\text { In vivo, } \\
\text { antimicrobial }\end{array}$ & $\begin{array}{c}\text { There was }>50 \% \text { mortality reduction in } 100 \mu \mathrm{g} / \mathrm{mL} \\
\text { treated shrimp, related with agglutination of Vibrio } \\
\text { parahaemolyticus }\end{array}$ & [25] \\
\hline $\begin{array}{l}\text { Hydropuntia } \\
\text { cornea }\end{array}$ & PBPs & In vitro, antifungal & $\begin{array}{l}\text { Dosage of } 0.3 \mathrm{mg} / \mathrm{mL} \text { inhibited Botrytis cinerea growth } \\
(33 \%) \text { and spore germination }(80 \%)\end{array}$ & [80] \\
\hline $\begin{array}{l}\text { Neopyropia } \\
\text { yezoensis }\end{array}$ & GP & $\begin{array}{l}\text { In vitro, } \\
\text { anti-inflammatory }\end{array}$ & $\begin{array}{l}\text { Inhibition of TLR } 4 \text { and ERK1/2 activation, inhibition } \\
\text { of NF-KB release }\end{array}$ & [86] \\
\hline Amansia multifida & Lectin & $\begin{array}{l}\text { In vivo, } \\
\text { anti-inflammatory }\end{array}$ & $\begin{array}{c}\text { Paw edema reduction against several } \\
\text { pro-inflammatory agents. Reduction in TNF- } \alpha \text {, IL-1 } \beta \\
\text { levels, and neutrophil migration. Increased } \\
\text { glutathione levels }\end{array}$ & [87] \\
\hline Eucheuma cottonii & $\begin{array}{l}\text { Lectin-rich } \\
\text { extract }\end{array}$ & $\begin{array}{l}\text { In vivo, } \\
\text { anti-inflammatory }\end{array}$ & $\begin{array}{c}\text { Decreased mucin synthesis, leucocyte infiltration, and } \\
\text { TNF- } \alpha, \text { NF- } k B, \text { IL-4, MMP-9, EGFR levels in } \\
\text { asthmatic rats }\end{array}$ & [88] \\
\hline $\begin{array}{l}\text { Briothamniun } \\
\text { triquetum }\end{array}$ & Lectin & $\begin{array}{c}\text { In vivo, } \\
\text { anti-inflammatory }\end{array}$ & $\begin{array}{l}\text { Reduced peritonitis and paw edema in treated mice. } \\
\text { Reduction in TNF- } \alpha \text {, IL-1 } \beta, \text { MPO levels, and } \\
\text { neutrophil migration. Better results than the } \\
\text { positive control }\end{array}$ & [42] \\
\hline
\end{tabular}


Table 2. Cont.

\begin{tabular}{|c|c|c|c|c|}
\hline Species & Protein(s) & Bioactivity & Mechanism of Action & Ref. \\
\hline Soliera filiformis & Lectin & In vitro, antitumor & $\begin{array}{c}\text { Apoptosis induction. Bcl-2 downregulation, } \\
\text { upregulation of caspases } 3,8,9\end{array}$ & [89] \\
\hline $\begin{array}{l}\text { Gracilaria } \\
\text { lemaneiformis }\end{array}$ & PE & In vitro, antitumor & $\begin{array}{l}\text { Apoptosis induction. Increased caspase 3/9 and } \\
\text { p53 expression }\end{array}$ & [90] \\
\hline $\begin{array}{c}\text { Portieria } \\
\text { hornemannii }\end{array}$ & R-PE & In vitro, antitumor & $\begin{array}{l}\text { Apoptosis induction. Cell cycle arrest at } \mathrm{G}_{2} / \mathrm{M} \text { phase, } \\
\text { membrane blebbing, and }>80 \% \text { cell deaths at } 1 \mathrm{mg} / \mathrm{mL}\end{array}$ & [91] \\
\hline Eucheuma serra & Lectin & In vitro, antitumor & $\begin{array}{l}\text { Apoptosis induction. Increased caspase-3 expression, } \\
\text { binding to mannose in human sarcoma cells. Complete } \\
\text { cancer cell death at } 2 \mu \mathrm{g} / \mathrm{mL} \text {, but not in normal cells }\end{array}$ & [92] \\
\hline $\begin{array}{l}\text { Bryothamnion } \\
\text { seaforthii }\end{array}$ & Lectin & $\begin{array}{l}\text { In vivo, } \\
\text { wound healing }\end{array}$ & $\begin{array}{l}\text { Induced greater inflammatory response, fibroblast } \\
\text { proliferation, and collagen synthesis. Reduced wound } \\
\text { size and faster closure in treated mice }\end{array}$ & [93] \\
\hline
\end{tabular}

Phaeophyceae

\begin{tabular}{|c|c|c|c|c|}
\hline $\begin{array}{l}\text { Sargassum } \\
\text { fusiforme }\end{array}$ & Lectin & In vitro, antioxidant & $\begin{array}{c}\text { Dosage of } 1.6 \mathrm{mg} / \mathrm{mL} \text { inhibited } 77.23 \% \text { DPPH; } 4 \\
\mathrm{mg} / \mathrm{mL} \text { inhibited } 68.97 \% \text { ABTS }\end{array}$ & [40] \\
\hline Saccharina japonica & GP & In vitro, antioxidant & $\begin{array}{c}\mathrm{DPPH}\left(\mathrm{IC}_{50}=0.12 \mathrm{mg} / \mathrm{mL}\right), \mathrm{ABTS}\left(\mathrm{IC}_{50}=0.05\right. \\
\mathrm{mg} / \mathrm{mL}), \mathrm{FRAP}\left(\mathrm{IC}_{50}=0.3 \mathrm{mg} / \mathrm{mL}\right) \text { and xanthine } \\
\text { oxidase }(70 \%, 0.2 \mathrm{mg} / \mathrm{mL}) \text { inhibition }\end{array}$ & [94] \\
\hline Undaria pinnatifida & GP & $\begin{array}{l}\text { In vitro, } \\
\text { antidiabetic }\end{array}$ & $\begin{array}{c}\text { Rat intestinal }\left(\mathrm{IC}_{50}=0.29 \mathrm{mg} / \mathrm{mL}\right) \text { and yeast }\left(\mathrm{IC}_{50}=\right. \\
0.11 \mathrm{mg} / \mathrm{mL}) \alpha \text {-glucosidase inhibition. Retained }>60 \% \\
\text { of inhibitory activity after thermal treatments }\end{array}$ & [95] \\
\hline \multicolumn{5}{|c|}{ Chlorophyceae } \\
\hline $\begin{array}{l}\text { Codium } \\
\text { isthmocladum }\end{array}$ & 2 lectins & In vitro, antibiofilm & $\begin{array}{l}\text { Binding to monosaccharide residues of the biofilms } \\
\text { with preference to } \alpha \text {-linkages }\end{array}$ & [71] \\
\hline Halimeda renschii & Lectin & In vitro, antiviral & $\begin{array}{c}\text { High mannose-binding lectin, bonded with Influenza } \\
\text { H3N2 viral envelope hemagglutinin, } \\
\text { preventing infection }\end{array}$ & [96] \\
\hline Boodlea coacta & Lectin & In vitro, antiviral & $\begin{array}{l}\text { High mannose-binding lectin binds to Influenza } \\
\text { hemagglutinin and HIV-1 GP gp120, avoiding infection }\end{array}$ & [97] \\
\hline \multirow{3}{*}{$\begin{array}{l}\text { Caulerpa } \\
\text { cupressoides }\end{array}$} & Lectin & $\begin{array}{l}\text { In vivo, } \\
\text { anti-inflammatory } \\
\text { and antinociceptive }\end{array}$ & $\begin{array}{l}\text { Analgesic effect as measured by paw licking time. } \\
\text { Reduced neutrophil infiltration }(65.9 \%) \text {, better than the } \\
\text { positive control }\end{array}$ & [98] \\
\hline & Lectin & $\begin{array}{c}\text { In vivo, } \\
\text { anti-inflammatory } \\
\text { and antinociceptive }\end{array}$ & $\begin{array}{c}\text { Reduced levels of TNF- } \alpha, \text { IL-1 } \beta, \text { MPO, and } \\
\text { leukocyte infiltration }\end{array}$ & [99] \\
\hline & Lectin & $\begin{array}{l}\text { In vivo, } \\
\text { anti-inflammatory }\end{array}$ & $\begin{array}{l}\text { IL-1 } \beta, \text { IL-6, TNF- } \alpha \text { and COX-2. Lower } \\
\text { neutrophil infiltration }\end{array}$ & [27] \\
\hline $\begin{array}{c}\text { Codium } \\
\text { decorticatum }\end{array}$ & GP & In vitro, antitumor & $\begin{array}{l}\text { Apoptosis induction. Mitochondrial membrane } \\
\text { alterations, caspase } 3 \text { and Bcl-2 genes upregulation }\end{array}$ & [35] \\
\hline
\end{tabular}

Notes and abbreviations. GP: Glycoprotein; GPs: glycoproteins: PE: Phycoerythrin; PBP: Phycobiliprotein DPPH: 2:2-diphenyl-1-picrylhydrazyl; ABTS: 2,2'-azino-bis(3-ethylbenzothiazoline-6-sulfonic acid); HIV: Human immunodeficiency virus; HSV: Herpes simplex virus; SARS-CoV: Severe acute syndrome-coronavirus; $\mathrm{IC}_{50}$ : Minimum half-inhibitory concentration; IL: Interleukin; TNF- $\alpha$ : Tumor necrosis factor- $\alpha$; EGFR: Epidermal growth factor receptor; NF-kB: Nuclear factor $k b$; TLR: Toll-like receptor; ERK: Extracellular receptor kinase; MPO: Myeloperoxidase; MMP: Matrix-metallopeptidase.

\subsection{Antihypertensive}

In the last decade, a wide number of reports have described a hypotensive effect of BAPs from all algae groups. Studies suggest that this effect may be due to an angiotensin I-converter enzyme (ACE) inhibition [26]. Another described mechanism of hypotensive activity is renin inhibition. Renin is an enzyme with various roles, including producing 
angiotensin I (ACE substrate) and stimulating renal activity [31]. Together, they constitute the known renin-ACE-aldosterone axis, which is the main pathway involved in cardiac pressure regulation [100]. Several studies confirming the anti-hypertensive properties of seaweed BAPs will be mentioned below and have been compiled in Table 3.

A study evaluated the effect of different proteases to obtain a G. lemaneiformis protein hydrolysate [52]. The results showed that trypsin produced the extract with the highest ACE inhibitory activity, up to $78 \%$. Further characterization of peptide sequence indicated that QVEY was the major BAP. A similar experiment was carried out with proteins obtained from $U$. intestinalis using Alcalase, $\alpha$-chymotrypsin, papain, pepsin, and trypsin. Again, trypsin produced the extract with the highest ACE inhibitory activity, and two peptides were indicated as the most active (FGMPLDR and MELVLR) [53]. Another related experiment regarding the use of different proteases to obtain BAPs from C. lentillifera indicated that thermolysin was the most appropriate choice in comparison to $\alpha$-chymotrypsin, pepsin, and trypsin. In this case, the peptides with the highest ACE inhibitory activity were FDGIP and AIDPVRA [101]. Among hydrolytic enzymes, pepsin is one of the most used in the last years. For instance, the peptide sequence NMEKGSSSVVSSRM (with anticoagulant activity) was obtained from the hydrolysis of N. yezoensis proteins using this enzyme [56]. A related experiment using $U$. rigida proteins indicated that the peptides with ACE inhibitory activity (IP and AFL) were obtained from the hydrolysis with pepsin [57]. In another experiment with this enzyme, peptides with ACE inhibitory activity (ALLAGDPSVLEDR and VVGGTGPVDEWGIAGAR) were also obtained from Bangia fusco-purpurea [102].

Another strategy to obtain hydrolysates from seaweeds is the use of sequential hydrolysis with different enzymes. This strategy was used to obtain peptides with ACE inhibitory activity from P. palmata [59]. In this case, the order of hydrolysis was thermolysin, pepsin, trypsin, and chymotrypsin. According to the authors, additional hydrolysis after thermolysin use did not increase the release of peptides with biological potential. Additionally, a reduction in total ACE inhibitory activity in the hydrolysate was obtained after consecutive hydrolysis with thermolysin, pepsin, and trypsin. The peptide sequence LRY was indicated as the most active from the thermolysin hydrolysate. In this sense, it seems reasonable to indicate that the selection of protease and the hydrolysis conditions have a great impact on the release of peptides with biological activity. Nonetheless, additional experiments are required to clarify the role of sequential hydrolysis in the release of bioactive peptides to characterize their protein hydrolyzation patterns and how this affects the properties of yielded BAPs.

The antihypertensive activity of BAPs has also been corroborated in vivo in several studies. For instance, Fitzgerald et al. obtained a renin-inhibitory peptide by hydrolyzing P. palmata protein isolates with papain, which sequence was IRLIIVLMPILMA [103]. The peptide showed ACE inhibition at very low concentrations $\left(\mathrm{IC}_{50}=0.32 \mathrm{mg} / \mathrm{mL}\right)$. The same team carried out an in vivo study with this same peptide on spontaneously hypertensive rats but obtained it by chemical synthesis. The effect of the peptide was compared with unpurified P. palmata hydrolysate, and the results showed that their effect was very similar, while a significant reduction in systolic blood pressure was achieved [104]. Another in vivo study reported that $U$. pinnatifida BAPs were able to significantly reduce blood pressure in spontaneously hypertensive rats. These BAPs were dipeptides mainly based on Tyr or Trp that showed this hypotensive effect with a single oral dose of $1 \mathrm{mg} / \mathrm{kg}$ body weight [105]. To our knowledge, the only clinical trial reporting a reduction in blood pressure was published in 2002 by Shirako Co. Ltd. researchers, which served as a scientific basis for developing and patenting this product. They reported that a $1.8 \mathrm{~g}$ /day intake of nori (Porphyra sp.) hydrolysate achieved a significant reduction in systolic blood pressure in hypertensive subjects (from 157 to $142 \mathrm{mmHg}$ ) but did not in normotensive ones ( $\leq 120 \mathrm{mmHg}$ ) [106]. 
Table 3. Bioactive peptides and hydrolysates obtained from seaweed proteins.

\begin{tabular}{|c|c|c|c|c|c|}
\hline Species & Hydrolysis & Sequence/s & Bioactivity & Results & Ref. \\
\hline \multicolumn{6}{|c|}{ Rhodophyceae } \\
\hline \multirow{2}{*}{$\begin{array}{l}\text { Gracilariopsis } \\
\text { lemaneiformis }\end{array}$} & $\begin{array}{l}\text { Trypsin; E:S (1:25), } \\
37^{\circ} \mathrm{C}, \mathrm{pH} 8,8 \mathrm{~h}\end{array}$ & QVEY & $\begin{array}{c}\text { In vitro, } \\
\text { antihypertensive }\end{array}$ & $\begin{array}{l}\text { ACE inhibitory activity. } \\
\mathrm{IC}_{50}=0.25 \mathrm{mg} / \mathrm{mL}\end{array}$ & {$[52]$} \\
\hline & $\begin{array}{l}\alpha \text {-Chymotrypsin; E:S } \\
(1: 25), 37^{\circ} \mathrm{C}, \mathrm{pH} 8,2 \mathrm{~h}\end{array}$ & ELWKTF & $\begin{array}{c}\text { In vitro, } \\
\text { antioxidant }\end{array}$ & $\begin{array}{l}\text { DPPH radical scavenging. } \\
\mathrm{EC}_{50}=1.51 \mathrm{mg} / \mathrm{mL}\end{array}$ & [58] \\
\hline Porphyra spp. & $\begin{array}{l}\text { Pepsin; E:S (1:100), } \\
\text { pH 2, } 45^{\circ} \mathrm{C}, 4 \mathrm{~h}\end{array}$ & GGSK, ELS & $\begin{array}{l}\text { In vitro, } \\
\text { antidiabetic }\end{array}$ & $\begin{array}{c}\alpha \text {-Amylase inhibition. } \\
\mathrm{IC}_{50}(\mathrm{GGSK})=0.8 \mathrm{mg} / \mathrm{mL} \\
\mathrm{IC}_{50}(\mathrm{ELS})=0.9 \mathrm{mg} / \mathrm{mL}\end{array}$ & {$[54]$} \\
\hline \multirow{4}{*}{ Porphyra dioica } & \multirow{3}{*}{$\begin{array}{c}\text { Alcalase }^{\circledR} \text { and } \\
\text { Flavourzyme }^{\circledR} ; \mathrm{E}: \mathrm{S} \\
(1: 100), 50^{\circ} \mathrm{C}, \mathrm{pH} 7,4 \mathrm{~h}\end{array}$} & $\begin{array}{l}\text { DYYLR, AGFY, YLVA, } \\
\text { AFIT, MKTPITE, } \\
\text { TYIA, LDLW }\end{array}$ & $\begin{array}{l}\text { In vitro, } \\
\text { antioxidant }\end{array}$ & $\begin{array}{c}\text { Most antioxidant on } \\
\text { ORAC assay: } \\
\mathrm{IC}_{50}(\mathrm{AFIT})=0.4 \mu \mathrm{g} / \mathrm{mL}, \\
\mathrm{IC}_{50}(\mathrm{MKTPITE})= \\
0.007 \mathrm{mg} / \mathrm{mL}\end{array}$ & [60] \\
\hline & & $\begin{array}{l}\text { DYYLR, AGFY, } \\
\text { YLVA, TYIA }\end{array}$ & $\begin{array}{l}\text { In vitro, } \\
\text { antihypertensive }\end{array}$ & $\begin{array}{c}\text { Most inhibiting BAPs: } \\
\left.\mathrm{IC}_{50} \text { (TYIA }\right)=0.04 \mathrm{mg} / \mathrm{mL}, \\
\mathrm{IC}_{50}(\text { TYIA })=0.07 \mathrm{mg} / \mathrm{mL}\end{array}$ & {$[60]$} \\
\hline & & YLVA & $\begin{array}{c}\text { In vitro, } \\
\text { antidiabetic }\end{array}$ & $\begin{array}{l}\text { DPP-IV inhibition, } \\
\mathrm{IC}_{50}=0.2 \mathrm{mg} / \mathrm{mL}\end{array}$ & [60] \\
\hline & $\begin{array}{l}\text { Prolyve }{ }^{\circledR} \text {; E:S (1:100), } \\
\quad 50^{\circ} \mathrm{C}, \mathrm{pH} 8,2 \mathrm{~h}\end{array}$ & $\begin{array}{l}\text { n.a., increased } \\
\text { production of }<1 \mathrm{kDa} \\
\text { peptides }\end{array}$ & $\begin{array}{c}\text { In vitro, } \\
\text { antioxidant }\end{array}$ & $\begin{array}{c}\text { ORAC }\left(\mathrm{IC}_{50}=2.7 \mathrm{mmol} \mathrm{TE} / \mathrm{g}\right) \\
\mathrm{DPPH}\left(\mathrm{IC}_{50}=\right. \\
0.2 \mathrm{mmol} \mathrm{TE} / \mathrm{g}), \mathrm{FRAP} \\
\left(\mathrm{IC}_{50}=0.4 \mathrm{mmol} \mathrm{TE} / \mathrm{g}\right)\end{array}$ & [107] \\
\hline \multirow{4}{*}{$\begin{array}{l}\text { Neopyropia } \\
\text { yezoensis }\end{array}$} & Chemical synthesis & IY, MKY, AKTSY, LRY & $\begin{array}{c}\text { Clinical trial, } \\
\text { antihypertensive }\end{array}$ & $\begin{array}{c}\text { Blood pression reduction } \\
\text { from } 157 / 95 \text { to } \\
142 / 86 \mathrm{mmHg} \text { with } \\
1.8 \mathrm{~g} / \text { day for } 35 \text { days }\end{array}$ & [106] \\
\hline & $\begin{array}{c}\text { Pepsin; E:S (1:40), pH 2, } \\
45^{\circ} \mathrm{C}, 2 \mathrm{~h}\end{array}$ & NMEKGSSSVVSSRM & $\begin{array}{c}\text { Ex vivo, } \\
\text { anticoagulant }\end{array}$ & $\begin{array}{l}\text { Blood clotting retardation; } \\
\quad \mathrm{IC}_{50}=4.49 \mu \mathrm{g} / \mathrm{mL}\end{array}$ & {$[56]$} \\
\hline & Chemical synthesis & "PPY" peptide & In vitro, antitumor & $\begin{array}{l}\text { Doses } \geq 125 \mathrm{ng} / \mathrm{mL} \\
\text { induced autophagy and } \\
\text { apoptosis in MCF-7 cells } \\
\text { via the mTOR pathway }\end{array}$ & [108] \\
\hline & Chemical synthesis & "PPY" peptide & $\begin{array}{c}\text { In vitro, } \\
\text { anti-inflammatory }\end{array}$ & $\begin{array}{c}\text { Doses } \geq 250 \mathrm{ng} / \mathrm{mL} \\
\text { inhibited expression of } \\
\text { inflammatory cytokines in } \\
\text { murine macrophages }\end{array}$ & [29] \\
\hline \multirow{4}{*}{$\begin{array}{l}\text { Pyropia } \\
\text { columbina }\end{array}$} & \multirow{2}{*}{$\begin{array}{l}\text { Alkaline protease; E:S } \\
(1: 40), 55^{\circ} \mathrm{C}, \mathrm{pH} 9.5,2 \mathrm{~h}\end{array}$} & \multirow{2}{*}{$\begin{array}{l}\text { n.a., } \sim 2.4 \mathrm{kDa} \\
\text { peptides }\end{array}$} & $\begin{array}{c}\text { In vitro, } \\
\text { antihypertensive }\end{array}$ & $\begin{array}{l}\text { ACE inhibitory activity. } \\
\mathrm{IC}_{50}=1.2 \mathrm{mg} / \mathrm{mL}\end{array}$ & [109] \\
\hline & & & $\begin{array}{l}\text { In vitro, } \\
\text { anticoagulant }\end{array}$ & $\begin{array}{c}\text { Antiplatelet aggregation. } \\
2.8 \mathrm{mg} / \mathrm{mL} \text { achieved } \\
18.7 \% \text { inhibition }\end{array}$ & [109] \\
\hline & $\begin{array}{l}\text { Trypsin; E:S (1:20), } \\
50^{\circ} \mathrm{C}, \mathrm{pH} 8,4 \mathrm{~h}\end{array}$ & n.a., >400 Da peptides & $\begin{array}{c}\text { In vitro, } \\
\text { antioxidant and } \\
\text { anti-inflammatory }\end{array}$ & $\begin{array}{c}\mathrm{DPPH}\left(\mathrm{IC}_{50}=2.8 \mathrm{mg} / \mathrm{mL}\right) \\
\text { ABTS }\left(\mathrm{IC}_{50}=2.4 \mathrm{mg} / \mathrm{mL}\right) \\
\text { upregulation of } \\
\text { IL10 at } 0.1 \mathrm{mg} / \mathrm{mL}\end{array}$ & {$[50]$} \\
\hline & $\begin{array}{l}\text { Fungal protease; E:S } \\
(1: 20), 55^{\circ} \mathrm{C}, \mathrm{pH} 4.3,3 \mathrm{~h} \\
\text { and Flavourzyme }{ }^{\circledR} ; \mathrm{E}: \mathrm{S} \\
(1: 50), 55^{\circ} \mathrm{C}, \mathrm{pH} 7,4 \mathrm{~h}\end{array}$ & n.a. & $\begin{array}{c}\text { In vitro, } \\
\text { anti-inflammatory }\end{array}$ & $\begin{array}{l}\text { Upregulation of IL-10 in } \\
\text { murine spenocytes, } \\
\text { macrophages and } \\
\text { lymphocytes at } \\
\geq 0.01 \mathrm{mg} / \mathrm{mL}\end{array}$ & [110] \\
\hline
\end{tabular}


Table 3. Cont.

\begin{tabular}{|c|c|c|c|c|c|}
\hline Species & Hydrolysis & Sequence/s & Bioactivity & Results & Ref. \\
\hline \multirow{4}{*}{$\begin{array}{l}\text { Palmaria } \\
\text { palmata }\end{array}$} & $\begin{array}{c}\text { Chymotrypsin; E:S } \\
(1: 20), \mathrm{pH} 8,30^{\circ} \mathrm{C}, 24 \mathrm{~h}\end{array}$ & 33 BAPs < 10 kDa & $\begin{array}{c}\text { In vitro, } \\
\text { antioxidant and } \\
\text { antihypertensive }\end{array}$ & $\begin{array}{c}\mathrm{A}<10 \mathrm{kDa} \text { fraction was } \\
\text { the most bioactive at } \\
\geq 0.75 \mathrm{mg} / \mathrm{mL}\end{array}$ & [55] \\
\hline & $\begin{array}{c}\text { Thermolysin; E:S } \\
(1: 100), 70^{\circ} \mathrm{C}, \mathrm{pH} 7,3 \mathrm{~h}\end{array}$ & LRY & $\begin{array}{c}\text { In vitro, } \\
\text { antihypertensive }\end{array}$ & $\begin{array}{c}\text { ACE inhibitory } \\
\mathrm{IC}_{50}=0.01 \mathrm{mg} / \mathrm{mL}\end{array}$ & [59] \\
\hline & $\begin{array}{c}\text { Papain; }(20.7 \mathrm{U} / \mathrm{mg} \\
\text { protein), } 60{ }^{\circ} \mathrm{C}, \mathrm{pH} 6, \\
24 \mathrm{~h}\end{array}$ & IRLIIVLMPILMA & $\begin{array}{c}\text { In vitro, } \\
\text { antihypertensive }\end{array}$ & $\begin{array}{l}\text { Renin inhibition. } \\
\mathrm{IC}_{50}=0.3 \mathrm{mg} / \mathrm{mL}\end{array}$ & [103] \\
\hline & Chemical synthesis & IRLIIVLMPILMA & $\begin{array}{c}\text { In vivo, } \\
\text { antihypertensive }\end{array}$ & $\begin{array}{l}\text { Systolic blood pressure } \\
\text { reduction from } 187 \text { to } \\
155 \mathrm{~mm} \mathrm{Hg} \text { at } 50 \mathrm{mg} / \mathrm{kg} \mathrm{bw}\end{array}$ & [104] \\
\hline $\begin{array}{c}\text { Bangia } \\
\text { fusco-purpurea }\end{array}$ & $\begin{array}{c}\text { Pepsin; E:S (1:200), } \\
\text { pH 7.5, } 37^{\circ} \mathrm{C}, 90 \mathrm{~min}\end{array}$ & $\begin{array}{l}\text { ALLAGDPSVLEDR, } \\
\text { VVGGTGPVDEW- } \\
\text { GIAGAR }\end{array}$ & $\begin{array}{c}\text { In vitro, } \\
\text { antihypertensive }\end{array}$ & $\begin{array}{c}\text { ACE inhibition. } \\
\text { IC }_{50} \text { (ALLAGDPSVLEDR) } \\
=57.2 \mathrm{mg} / \mathrm{mL} \\
\text { IC }_{50}(\text { VVGGTGPVDEW } \\
\text { GIAGAR) }=66.2 \mu \mathrm{g} / \mathrm{mL}\end{array}$ & [102] \\
\hline
\end{tabular}

Phaeophyceae

\begin{tabular}{|c|c|c|c|c|c|}
\hline $\begin{array}{l}\text { Saccharina } \\
\text { longicruris }\end{array}$ & $\begin{array}{l}\text { Trypsin; E:S (1:20), } \\
\mathrm{pH} 7,30^{\circ} \mathrm{C}, 24 \mathrm{~h}\end{array}$ & $\begin{array}{c}\text { EAESSLTGGNGCAK, } \\
\text { IGNGGELPR, } \\
\text { ILVLQSNQIR, } \\
\text { ISAILPSR, } \\
\text { ISGLIYEETR, } \\
\text { LPDAALNR, } \\
\text { MALSSLPR, } \\
\text { QVHPDTGISK, TI- } \\
\text { TLDVEPSDTIDGVK }\end{array}$ & $\begin{array}{c}\text { In vitro, } \\
\text { antimicrobial }\end{array}$ & $\begin{array}{c}\text { Mix of all peptides } \\
(2.50 \mathrm{mg} / \mathrm{mL}) \text { inhibited } \\
40 \% \text { Staphylococcus aureus } \\
\text { growth }\end{array}$ & [81] \\
\hline $\begin{array}{l}\text { Sargassum } \\
\text { maclurei }\end{array}$ & $\begin{array}{c}\text { Pepsin; }(80 \mathrm{U} / \mathrm{g} \\
\text { protein), } 37^{\circ} \mathrm{C}, \mathrm{pH} 2, \\
2 \mathrm{~h} \text { and Papain; } \\
\left(60 \mathrm{U} / \mathrm{g} \text { protein), } 50^{\circ} \mathrm{C},\right. \\
\text { pH } 7,3 \mathrm{~h}\end{array}$ & RWDISQPY & $\begin{array}{l}\text { In vivo and } \\
\text { in vitro, } \\
\text { antihypertensive }\end{array}$ & $\begin{array}{l}\text { Systolic blood pressure } \\
\text { reduction from } 170 \text { to } \\
150 \mathrm{~mm} \mathrm{Hg} \text { at } 100 \mathrm{mg} / \mathrm{kg} \\
\text { bw; } 25 \% \text { endothelin- } 1 \\
\text { inhibition at } 1.5 \mathrm{mg} / \mathrm{mL}\end{array}$ & {$[21]$} \\
\hline $\begin{array}{l}\text { Laminaria } \\
\text { japonica }\end{array}$ & $\begin{array}{l}\text { Alcalase }{ }^{\circledR} \text {, papain, } \\
\text { trypsin, and pepsin; } \\
55^{\circ} \mathrm{C}, \mathrm{pH} 7.5 \text {. E:S and } \\
\text { time not specified }\end{array}$ & $\begin{array}{c}\text { KY, GKY, SKTY, AKY, } \\
\text { AKY, AKYSY, KKFY, } \\
\text { FY, KFKY }\end{array}$ & $\begin{array}{c}\text { In vitro, } \\
\text { antihypertensive }\end{array}$ & $\begin{array}{c}\text { ACE inhibition. } \\
\text { Hydrolysate of all } \\
\text { combined proteases } \\
\text { achieved } \\
\mathrm{IC}_{50}=0.6 \mathrm{mg} / \mathrm{mL}\end{array}$ & [111] \\
\hline \multirow{3}{*}{$\begin{array}{l}\text { Undaria } \\
\text { pinnatifida }\end{array}$} & $\begin{array}{l}\text { Hot water; } 93^{\circ} \mathrm{C}, \\
20 \mathrm{~min}\end{array}$ & $\begin{array}{c}\text { YH, KW, KY, KF, VW, } \\
\text { VF, IY, IW, VY }\end{array}$ & $\begin{array}{c}\text { In vivo, } \\
\text { antihypertensive }\end{array}$ & $\begin{array}{l}\text { Systolic blood pressure } \\
\text { reduction }(25-34 \mathrm{~mm} \mathrm{Hg}) \\
\text { by } 10 \mathrm{mg} / \mathrm{kg} \text { bw for } \\
1 \text { week }\end{array}$ & [112] \\
\hline & $\begin{array}{l}\text { Pepsin; E:S (100:1), } \\
45^{\circ} \mathrm{C}, \mathrm{pH} 2,18 \mathrm{~h}\end{array}$ & $\begin{array}{c}\text { YH, KW, KY, KF, VW, } \\
\text { VF, IY, IW, VY }\end{array}$ & $\begin{array}{c}\text { In vivo, } \\
\text { antihypertensive }\end{array}$ & $\begin{array}{l}\text { Systolic blood pressure } \\
\text { reduction (14-21 mm Hg) } \\
\text { by } 1 \mathrm{mg} / \mathrm{kg} \text { bw for } 1 \text { week }\end{array}$ & [105] \\
\hline & $\begin{array}{c}\text { Bromelain; }(12 \mathrm{kU} / \mathrm{g} \\
\text { protein }), 45^{\circ} \mathrm{C}, \\
\mathrm{pH} 6,4 \mathrm{~h}\end{array}$ & KNFL & $\begin{array}{c}\text { In vitro, } \\
\text { antihypertensive }\end{array}$ & $\begin{array}{l}\text { ACE inhibition. } \\
\mathrm{IC}_{50}=1.3 \mu \mathrm{g} / \mathrm{mL}\end{array}$ & [113] \\
\hline \multicolumn{6}{|c|}{ Chlorophyceae } \\
\hline Ulva intestinalis & $\begin{array}{l}\text { Trypsin; E:S (1:25), } \\
37^{\circ} \mathrm{C}, \mathrm{pH} 8,5 \mathrm{~h}\end{array}$ & FGMPLDR, MELVLR & $\begin{array}{c}\text { In vitro, } \\
\text { antihypertensive }\end{array}$ & $\begin{array}{c}\text { ACE inhibition. } \\
\mathrm{IC}_{50}(\text { FGMPLDR, } \\
\text { MELVLR })=0.18 \mathrm{mg} / \mathrm{mL}\end{array}$ & {$[53]$} \\
\hline Ulva rigida & $\begin{array}{l}\text { Pepsin; E:S (1:100), } \\
\text { pH 2.0, } 37^{\circ} \mathrm{C} 20 \mathrm{~h}\end{array}$ & IP, AFL & $\begin{array}{c}\text { In vitro, } \\
\text { antihypertensive }\end{array}$ & $\begin{array}{c}\text { ACE inhibition. } \mathrm{IC}_{50}(\mathrm{IP} \\
\mathrm{AFL})=0.2 \mathrm{mg} / \mathrm{mL}\end{array}$ & [57] \\
\hline
\end{tabular}


Table 3. Cont.

\begin{tabular}{|c|c|c|c|c|c|}
\hline Species & Hydrolysis & Sequence/s & Bioactivity & Results & Ref. \\
\hline Ulva lactuca & $\begin{array}{l}\text { Papain; E:S (1:100), } \\
60^{\circ} \mathrm{C}, \mathrm{pH} 6,24 \mathrm{~h}\end{array}$ & $\begin{array}{l}55 \text { non-allergenic } \\
\text { BAPs identified }\end{array}$ & $\begin{array}{l}\text { In vitro, } \\
\text { antihypertensive }\end{array}$ & $\begin{array}{c}\text { ACE inhibition }(93 \%) \text { in } \\
>1 \text { kDa hydrolysate fraction }\end{array}$ & [114] \\
\hline $\begin{array}{l}\text { Enteromorpha } \\
\text { clathrata }\end{array}$ & $\begin{array}{l}\text { Alcalase }^{\circledR} ; 2.9 \mathrm{kU} / \mathrm{g} \\
\text { protein, T not stated, } \\
\text { pH 7.6, } 90 \mathrm{~min}\end{array}$ & PAFG & $\begin{array}{l}\text { In vitro, } \\
\text { antihypertensive }\end{array}$ & $\begin{array}{c}\text { ACE inhibition. } \\
\mathrm{IC}_{50}=0.014 \mathrm{mg} / \mathrm{mL}\end{array}$ & [115] \\
\hline $\begin{array}{l}\text { Caulerpa } \\
\text { lentillifera }\end{array}$ & $\begin{array}{l}\text { Thermolysin; E:S (1:50), } \\
60^{\circ} \mathrm{C}, \mathrm{pH} 8.5,16 \mathrm{~h}\end{array}$ & FDGIP, AIDPVRA & $\begin{array}{c}\text { In vitro, } \\
\text { antihypertensive }\end{array}$ & $\begin{array}{c}\text { ACE inhibition. } \mathrm{IC}_{50} \\
(\mathrm{FDGIP})=0.03 \mathrm{mg} / \mathrm{mL} \\
\mathrm{IC}_{50}(\mathrm{AIDPVRA})=0.04 \mathrm{mg} / \mathrm{mL}\end{array}$ & [101] \\
\hline
\end{tabular}

Abbreviations: E:S: Enzyme:substrate $(w / w) ; \mathrm{IC}_{50}$ : Half-inhibitory concentration; TE: Trolox equivalents: BAPs: bioactive peptides; ACE: angiotensin I-converter enzyme; DPPH: 2,2-diphenyl-1-picrylhydrazyl; ABTS: (2,2'azino-bis(3-ethylbenzothiazoline-6-sulfonic acid)); IL: interleukin; ORAC: oxygen radical absorbance capacity; FRAP: ferric reducing ability of plasma; mTOR: mammalian target of rapamycin.

\subsection{Anti-Inflammatory}

Inflammation is a complex response to cell and/or tissue damage, which can be triggered by several factors, such as oxidative damage, infections, or cancer [116]. These processes and cellular interactions involve pro- and anti-inflammatory mediators, which up- or downregulate the inflammatory response. Therefore, the mechanisms by which $\mathrm{SP}$ and BAPs have been described to induce anti-inflammatory effects, both in vitro and in vivo, are related to an increased expression of anti-inflammatory mediators and/or downregulation of the expression of pro-inflammatory ones. The main pro-inflammatory mediators are cytokines like interleukins (IL) (e.g., IL-1 $\beta, 2,6$, and 8) and also tumor necrosis factor- $\alpha$ (TNF- $\alpha$ ). Other compounds like the prostaglandin cyclooxygenase-2 $(\mathrm{COX}-2)$ or the chemokine inducible nitric oxide synthase (iNOS) also play a vital role in inducing an inflammatory response, especially producing ROS and nitric oxide (NO), which mainly activate macrophages. These cells, when activated, e.g., via toll-like receptors (TLR), lead these innate immune cells to release IL-6, TNF- $\alpha$, and also transforming growth factor- $\beta$, which promotes cell proliferation [117]. The nuclear factor $\kappa \mathrm{B}(\mathrm{NF}-\mathrm{\kappa B})$ and mitogen-activated protein kinase (MAPK) are also key pro-inflammatory intermediaries that are produced after TLR activation [118].

Regarding SP with anti-inflammatory activity, most of the studies point to lectins as prime examples. In fact, several in vivo experiments show that these proteins exert anti-inflammatory properties through various pathways. For example, various works have assessed the in vivo anti-inflammatory activity of lectins isolated from the green alga C. cupressoides (Table 2). Mice submitted to high concentrations of carrageenan to induce inflammatory response were treated with $C$. cupressoides lectins administered intravenously. The lectin treatment showed similar results to that of dexamethasone, significantly reducing inflammation signals, such as neutrophil levels and paw edema. Additionally, the lectins appeared to reduce nociception while not displaying any significant variation in organs weight or transaminase levels [98]. Very similar results were obtained in rats with temporomandibular induced arthritis. In this study, after the same treatment, the tissue showed a significant decrease in TNF- $\alpha$, IL-1 $\beta$, and myeloperoxidase (MPO) levels, as well as a significant reduction in leukocyte concentration [99]. Additionally, it was found that lectin treatment was able to reverse the tissue damage and exert an analgesic effect via a non-opioid pathway. In another work, the authors described the molecular pathway through which the lectin from C. cupressoides exerts anti-inflammatory effects, using several pro-inflammatory agents injected in rat paws [27]. A combination of enzymatic and immunohistochemistry staining methods unveiled that this lectin elicited an anti-inflammatory effect by inhibiting the primary cytokines IL-1 $\beta$, IL-6, TNF- $\alpha$, and $\mathrm{COX}-2$, as well as lowering neutrophil infiltration, as demonstrated by reduced MPO levels. However, no inhibition of hemeoxygenase-2 (HO-2) was observed. Additionally, the authors confirmed that the anti-inflammatory effect was due to the carbohydrate-binding 
site of the lectin since when co-administered with mucin, its anti-inflammatory effect was inhibited. This was confirmed by testing the anti-inflammatory effect of the lectin not only against carrageenan but also against dextran and histamine, with successful reductions in paw edemas. However, when directly injected into rat paws instead of intravenously, the lectin induced a strong inflammatory response, which is related to the absent interaction with pro-inflammatory agents but also to the administration route [27]. A $30 \mathrm{kDa}$ lectin purified from Amansia multifida displayed similar effects, modulating paw edema and peritonitis formation in mice [87]. This lectin consistently ameliorated paw edema against carrageenan, histamine, prostaglandin E2, and compound 48/80 (an inducer of histamine release). Pre-treatment with this lectin also greatly reduced neutrophil infiltration following carrageenan-induced peritonitis, as well as significantly lower TNF- $\alpha$ IL- $1 \beta$ expression in the affected tissue (Table 2). Moreover, its administration showed lower MPO activity, with values even lower than those observed for indomethacin. Its anti-inflammatory effect was also confirmed by the increased levels of glutathione, which were greater than in the control group, thus indicating that its anti-inflammatory property is also related to preventing further oxidative damage [87].

Other studies have reported the anti-inflammatory properties of other SP, although few examples can be found. For instance, a $3.5 \mathrm{kDa}$ GP from $N$. yezoensis was tested in vitro lipopolysaccharide (LPS)-activated murine RAW 264.7 macrophages [86]. This GP reduced IL-1 receptor-associated kinase 4 binding to the macrophages' TLR4, which inhibited NF- $\kappa B$ and resulted in lower production of TNF- $\alpha, \mathrm{IL}-1 \beta, \mathrm{COX}-2$, and iNOS. Additionally, phosphorylation of Jun N-terminal kinase (JNK) and extracellular signal-related kinase (ERK) was lowered, which are also relevant mediators to the MAPK inflammatory pathway [86].

BAPs have also been reported to ameliorate inflammatory responses, but only in vitro. For instance, $P$. columbina hydrolysates managed to induce anti-inflammatory responses [110]. Using macrophages, T lymphocytes, and splenocytes isolated from rat spleen, cell toxicity, proliferation, and cytokine production were assessed. The authors found that the hydrolysate showed no toxicity, and, in combination with concanavalin A (a lymphocyte mitogen), it exerted a synergistic effect on lymphocyte proliferation. The hydrolysate also decreased TNF- $\alpha$ and IL- 6 while increasing IL-10 release. The observed anti-inflammatory effect was, therefore, due to an increased IL-10 release, as this interleukin acts as an anti-inflammatory mediator in macrophages and lymphocytes while suppressing the MAPK and NF- $\mathrm{BB}$ dependent pathways. The same team tested the anti-inflammatory potential of an SP hydrolysate obtained from the simultaneous hydrolyzation of various Ulva species [62]. Employing the same experimental model as in the previous work, the anti-inflammatory pathways of this hydrolysate were tested. These hydrolysates showed an anti-inflammatory but also an immunomodulatory effect [62]. Similarly, in vitro antiinflammatory potential of the BAP PPY1 from N. yezoensis was tested. Using LPS-stimulated RAW 264.7 macrophages, the authors found reduced expression of iNOS, COX-2, IL-1 $\beta$, and NF- $\kappa$ B. This downregulation of pro-inflammatory mediators was linked to lower expression of p38 mitogen-activated protein kinases and JNK [29].

\subsection{Antitumoral}

Cancer is a complex disease characterized by uncontrolled cell proliferation. Inflammation, oxidative stress, and immunomodulation have interconnected roles on cancer as inducer factors but also as outcomes of it [119]. Among several cancer treatment options, cytostatic agents or specific antitumor molecules are the focus of novel anticancer drugs [120]. Although there are several pathways resulting in cell apoptosis, the major mechanisms are regulated by caspase proteins, the mammalian target of rapamycin (mTOR), and others, like up- or downregulation of Bcl-2 family genes or inhibition of protein-53. In this sense, several SP and BAPs have been described to exert antitumoral effects on various in vitro models. However, in vivo studies are still necessary to assess their potential.

Lectins play a role in immunology by agglutinating the carbohydrate domain of several membrane GPs. This allows seaweed mannose-specific lectins to bind to specific 
GPs from certain tumoral cells and block their proliferation. Although reports on specific anticancer studies testing seaweed lectins are scarce, a recent study reported anticancer properties from two S. filiformis lectins [89]. Testing on human breast (MCF-7) cancer cells, it was found that these lectins induced apoptosis, relating to downregulation of antiapoptotic genes like Bcl-2 and upregulation of proapoptotic genes like Bax and caspases 3,8 , and 9 . The authors determined that this anticancer activity could also be due to the mannose oligosaccharides present in the MCF-7 cells surface, for which these lectins were specific [89]. Another study reported that PE from G. lemaneiformis induced apoptosis in human colon (SW480) cancer cells. Following a thorough proteomic and morphological analysis, exposition to PE resulted in a loss of cell adherence, arresting the cell cycle at $\mathrm{S}$ and $\mathrm{G}_{2} / \mathrm{M}$ phases, and inducing apoptosis. Apoptosis was evidenced by flow cytometry but also by significant expression of the apoptotic genes for caspase- 9 and 3 and protein- 53 . The loss in cell adherence, besides observed cells, was demonstrated by a lower expression of annexin A2, which resulted in lower cell adherence and is also related to an upregulation of caspase-3 or protein-53 [90]. Similarly, R-PE from Portiera hornemannii was tested against hepatic (HepG2) and lung (A549) carcinoma cells. Their results indicated that this R-PE induced apoptosis in these cancer cell lines by arresting the cell cycle at the $\mathrm{G}_{2} / \mathrm{M}$ phase, reducing cell proliferation, and leading to DNA fragmentation. This was demonstrated by fluorescence microscopy, which evidenced that this response was dose-dependent [91]. MAAs have also been described to possess antitumoral properties to a certain degree, possibly because of their potent antioxidant activity. Various MAA-rich extracts from C. chrispus, M. estellatus, and P. palmata were tested for their anticancer activity against cervical (HeLa) cancer and lymphoma (U937) cells [121]. The study determined that these extracts increased the activity of caspases 3 and 7, which was related to changes in cells to apoptotic morphology.

Regarding BAPs, few studies have corroborated their antitumoral properties. For example, the peptide PPY from $N$. yezoensis was reported to induce apoptosis in MCF-7 cancer cells. The study focused on the PPY potential to inhibit the insulin-like growth factorI receptor (IGF-IR), as its overexpression is related to tumor proliferation and survival. After fluorescent staining, a reduction in cell proliferation and increased apoptosis was observed. The underlying molecular mechanism was related to a decreased activation of $\mathrm{p} 85$, which is a subunit of phosphatidylinositol 3-kinases (PI3K) and is a critical regulator of cell proliferation and differentiation. Additionally, IGF-R expression was significantly reduced, as well as ERK, which decreased inflammation and induced apoptosis. Cell cycle arrest was evidenced by cyclins down-expression, which was correlated with the cyclin inhibitors p21 and p27 [122]. The same team later described that these anticancer effects of PPY were also related to an upregulation of mTOR, among other key apoptosis inducers. Additionally, these MCF-7 cells also showed downregulation of p70S6 kinase, the expression of which is related to cancer metastasis [108].

\subsection{Anti-Diabetic and Anti-Obesity}

Type 2 diabetes mellitus and obesity are metabolic syndromes developed by hormonal and/or diet imbalances that may derive from several related diseases. To prevent or ameliorate these diseases, there are several known target molecules, such as dipeptidyl peptidase-IV (DPP-IV) and the digestive enzymes $\alpha$-glucosidase and $\alpha$-amylase. DPPIV is a transmembrane exopeptidase enzyme that degrades proteinic hormones, such as the glucagon-like peptide-1 (GLP-1). Both $\alpha$-glucosidase and $\alpha$-glucosidase metabolize glucose and starch, respectively, in the small intestine [123]. GLP-1 is an incretin hormone that induces the secretion of glucose-dependent insulin, as well as producing a satiety sensation [124]. Therefore, inhibiting the action of these mentioned enzymes and promoting secretion of both GLP-1 and insulin would result in improved management of total glucose plasma levels and metabolic function.

According to the literature, most of the studies reporting anti-diabetic and antiobesity properties of seaweed compounds are related to BAPs. For instance, BAPs from 
$N$. haitanensis, obtained by ultrasound extraction and simulated gastric digestion, showed $\alpha$-glucosidase inhibitory effects. The peptides were separated into several fractions by gel chromatography, and those with higher peptide content and lower MW displayed more antioxidant and inhibitory activities [68]. Similarly, BAPs from a $<3$ kDa Porphyra spp. hydrolysate fraction displayed very high $\alpha$-amylase-inhibitory activity. The inhibitory activity was confirmed by artificial synthesis of the peptides, achieving inhibition of $\mathrm{IC}_{50}=2.58 \mathrm{mM}$. Further isolation of peptides revealed that GGSK and ELS were the most relevant BAPs [54]. As noted by the authors, this inhibition mechanism was not only related to the lower MW of the peptides but also that it was non-competitive with the substrate. Several studies have also shown the inhibitory activity against DPP-IV of P. palmata SP hydrolysates and BAPs. An SP hydrolysate from this alga significantly inhibited DPP-IV, with an $\mathrm{IC}_{50}$ of $1.17 \mathrm{mg} / \mathrm{mL}$, which was a quarter of the concentration needed for the untreated protein isolate to achieve the same inhibition rate [125]. Similar results were reported for other hydrolysates obtained with different proteases. Hydrolysate produced with Corolase ${ }^{\circledR}$ displayed the most significant inhibition $\left(\mathrm{IC}_{50}=1.65 \mathrm{mg} / \mathrm{mL}\right)$. Interestingly, the hydrolysate obtained from the aqueous-soluble fraction was more active $\left(\mathrm{IC}_{50}=3.16 \mathrm{mg} / \mathrm{mL}\right)$ than that of the alkaline-soluble one, and the combination of both fractions showed an intermediate activity $\left(\mathrm{IC}_{50}=2.26 \mathrm{mg} / \mathrm{mL}\right)$ [126]. Several BAPs from $P$. palmata hydrolysate with DDP-IV, ACE inhibition, and antioxidant activities were identified. The authors cross-checked these isolated peptide sequences and found that many of these were part of PBPs and the RuBisCo large subunit, which indicates that these proteins may contain the most bioactive peptide sequences [60]. Finally, it has been reported that a BAP from $N$. yezoensis stimulated the proliferation and differentiation of murine small intestine cells [127]. This was achieved at concentrations from $1 \mu \mathrm{g} / \mathrm{mL}$ by triggering the IGF-IR signaling pathway, which induces diverse changes in key protein expression in the cell nucleus and leads to cell differentiation. The authors analyzed that this occurred via upregulation of this receptor's substrates such as IGF-IR, insulin receptor substrate-I (IRS-I), sarcoma homology collagen, and phosphotyrosine. This upregulation inducing an increased response of IGF-IR leads to the activation of other related pathways that result in tissue development and angiogenesis without increasing an inflammatory response. This effect of $N$. yezoensis BAP may be accounted for a functional role in small intestinal epithelial tissue development [127].

Anti-diabetic and anti-obesity effects of seaweed BAPs have also been corroborated by in vivo studies. A study reported that oral treatment for 18 days with $P$. palmata hydrolysate to diabetic mice resulted in a significant reduction in glycemia, increased insulin secretion, and reduced glycated hemoglobin levels. Moreover, this protein hydrolysate also reduced energy intake and increased total plasma GLP-1 levels. The most relevant highlight of the study was that these responses were not statistically different from those of the positive control (metformin) under the same treatment conditions [128]. The same team assessed several insulinotropic and toxicity effects of a P. palmata hydrolysate digested with different proteases and simulated gastric digestion. Using various suitable pancreatic, adipose and enteroendocrine cell cultures, they found that not only the hydrolysates did inhibit DPP-IV, but also increased insulin and GLP-1 secretion. The authors inferred that this was due to an actual response and not the release of these molecules following cell death. An increase in calcium transmembrane mobilization, as well as an upregulation of cyclic adenosine monophosphate (cAMP) was found liable for the overall incretin effect. When testing these effects in vivo with mice (100 $\mathrm{mg} / \mathrm{kg}$ body weight), it was found an improved glucose tolerance, as well as satiety response after $90 \mathrm{~min}$ of oral administration, which would indicate a positive increase in GLP-1 and other incretin upregulation [129].

\section{Potential Applications}

\subsection{Seaweed Proteins}

Considering the described biological properties of SPs, several potential applications have been proposed. One of the most promising SP groups is lectins due to their broad 
range of bioactivities described. Based on their antimicrobial and antiviral properties, seaweed lectins could be considered as new ingredients for the formulation of treatments against some pathogens. Indeed, as mentioned before, the lectin griffithsin has been described to be able to treat and prevent infections in both rats and macaques, specifically of Influenza, HSV, and HIV [75]. Topical application of this lectin in pharmaceutical formulations could prove to be a possible preventive treatment against these infections, as evidenced by multiple reports. Moreover, seaweed lectins from diverse sources have shown to be effective at pico- or nanomolar concentrations for exerting either antimicrobial, anti-inflammatory, or antitumor effects (Figure 4). In this last regard, many studies have assessed the potential cytotoxicity of these lectins, finding very low cytotoxicity indexes or even no binding with healthy cells, in contrast to tumoral ones [92]. The anti-inflammatory effect of different lectins also supports potential pharmaceutical applications, especially in the case of C. cupressoides lectin, as it displays in vivo analgesic effects [27].

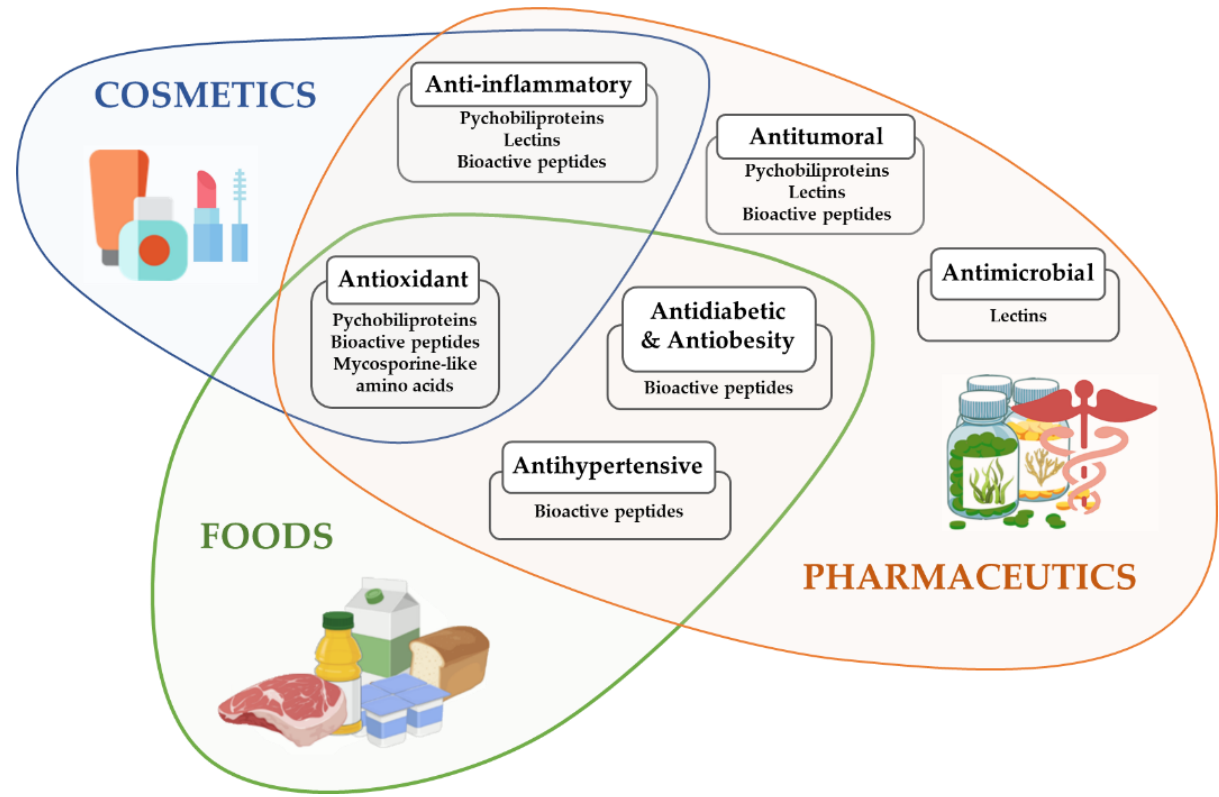

Figure 4. Potential applications of seaweed proteins, bioactive peptides, and Mycosporine-like amino acids considering their described bioactivities. Several properties of these molecules may be applied to diverse fields and industries in different formulations.

Regarding PBPs and MAAs, they could also be considered useful compounds for further industrial applications. PBPs, such as PE, are currently used as fluorescent probes in biochemistry, but their antioxidant, anti-inflammatory, and antitumoral properties suggest further applications. Indeed, they can be used as colorants in foods, as well as functional ingredients, based on their antioxidant properties. For instance, this was tested in edible films with incorporated P. columbina R-PE, which displayed antioxidant activity [130]. On the other hand, MAAs are excellent antioxidant molecules, which, paired with their very low cytotoxicity and high thermal resistance, make them ideal food additives [121]. Considering that MAAs seem to play a specific role as UV oxidation protectors in seaweeds, these could also be included in cosmetics such as sunscreens [131].

\subsection{Bioactive Peptides}

Scientific evidence supports the biological effects of seaweed BAPs (Table 3), as it has also been reported with BAPs from other protein sources [132,133]. The main biological effects reported are related to the improvement of hypertension, often described by inhibiting ACE or renin activities $[52,101,126]$. Given that this effect has been verified in various in vivo experiments [21,112] and also reported in human subjects [106], there is a scientific basis to suggest that seaweed BAPs should be considered as cardioprotective 
agents. Additionally, some BAPs from N. yezoensis were reported to exert anticoagulant activity, which would contribute to cardiac function in some cases [56].

Seaweed BAPs have also been described to be potent antioxidant molecules at low concentrations and in various antioxidant assays [107]. This suggests that their use as a functional ingredient in foods or cosmetics could be multivalent, acting as preservers and/or dietary antioxidant compounds.

Furthermore, BAPs, such as described from P. palmata, are reported to exert antidiabetic and anti-obesity effects [128]. Foremost, these effects are related to upregulation of GLP-1 and/or inhibition of DPP-IV, which results in an improved metabolic function and control of glucose levels [60]. Seaweed BAPs may also act as $\alpha$-glucosidase inhibitors, reducing gut glucose absorption and subsequent glycemic levels [54]. Given that these effects have been described in animal models, there is a great potential for these peptides as dietary supplements for diabetes and/or obesity management $[128,129]$. The anti-inflammatory or antitumoral properties of seaweed BAPs have also been highlighted. Anti-inflammatory effects of seaweed BAPs are mostly related to the upregulation of antiinflammatory cytokines such as IL10, ameliorating inflammatory reactions [110], but also through immunomodulation [62]. Regarding antitumoral effects, while available reports have only been performed in vitro, several works describe these peptides to induce apoptosis while showing almost null cytotoxicity $[108,134]$. However, while there is abundant evidence of in vitro describing molecular effects of these BAPs, more animal studies are required to validate and corroborate these properties to devise effective applications. Notably, the great majority of seaweed BAPs are of short length, which has proven to make them resistant to gastrointestinal digestions and retain their biological properties, such as antihypertensive or antioxidant $[104,105]$. This fact further supports their suitability as food additives or dietary supplements.

Altogether, even though accumulating reports support the bioactive properties of seaweed BAPs, additional studies are necessary to improve the knowledge about the use of seaweed protein hydrolysates and bioactive peptides in different systems and fields of research. Further research should focus on deeper studies about effects in vivo and direct applications in (i.e., pharmacological, food science, and cosmetics) to explore the wide variety of activities of seaweed peptides.

\section{Conclusions}

Seaweeds are being increasingly exploited on a global scale due to their dietary and nutritional benefits, of which their protein and amino acid composition pose a valuable component. Considering their protein content and bioactivities, seaweeds can be feasible to use as a source of these compounds with functional properties. SP such as red algae's PBPs, as well as lectins, have been extensively studied in recent years as potential new functional ingredients or pharmacological agents since significant evidence supports their use as anti-inflammatory, antitumoral, or antiviral agents. Moreover, SP hydrolysates contain several BAPs, which have been isolated and demonstrated to possess effective biological properties such as the ones mentioned above but also to be anti-diabetic or anti-obesity agents, as well as important hypotensive molecules. Several works have analyzed the potential mechanisms of action of these proteins and derived peptides, highlighting their effective potential for various applications. Altogether, despite the growing evidence on SP and their derived BAPs, much further work is needed to evaluate the extent of their possible mechanisms of action. Likewise, further works would need to assess potential bioactive SP in many species, especially from green or brown algae, as these are less studied groups.

Author Contributions: Conceptualization, J.E. and M.A.P.; methodology, J.E. and P.G.-O.; software, J.E., P.E.S.M., M.P. and P.G.-O.; validation, J.M.L., J.S.-G. and M.A.P.; formal analysis, J.E., P.O. and M.A.P.; investigation, J.E., P.O., P.E.S.M. and M.P.; data curation, J.E., P.E.S.M. and M.P.; writingoriginal draft preparation, J.E., P.O., P.E.S.M. and M.P.; writing-review and editing, P.G.-O., J.E., M.A.P. and J.M.L.; visualization, P.O., J.S.-G., M.A.P. and J.E.; supervision, M.A.P., J.S.-G. and J.M.L. All authors have read and agreed to the published version of the manuscript. 
Funding: The research leading to these results was supported by MICINN supporting the Ramón y Cajal grant for M.A. Prieto (RYC-2017-22891), to Xunta de Galicia for the pre-doctoral grant of P. Garcia-Oliveira (ED481A-2019/295), the program Grupos de Referencia Competitiva (GRUPO AA1-GRC 2018) that supports the work of J. Echave, to the Bio Based Industries Joint Undertaking (JU) under grant agreement No 888003 UP4HEALTH Project (H2020-BBI-JTI-2019) that supports the work of P. Otero. The JU receives support from the European Union's Horizon 2020 research and innovation program and the Bio Based Industries Consortium. P.E.S. Munekata, M. Pateriro, and J.M. Lorenzo acknowledge GAIN (Axencia Galega de Innovación) for supporting this study (grant number IN607A2019/01).

Conflicts of Interest: The authors declare no conflict of interest.

\section{Abbreviations}

\begin{tabular}{|c|c|}
\hline SP & Seaweed proteins \\
\hline AA & Amino acids \\
\hline EAA & Essential amino acids \\
\hline NEAA & Non-essential amino acids \\
\hline BAPs & Bioactive peptides \\
\hline GP & Glycoprotein \\
\hline PBP & Phycobiliprotein \\
\hline PE & Phycoerythrin \\
\hline MAAs & Mycosporine-like amino acids \\
\hline$\lambda_{\max }$ & Absorption maxima \\
\hline ORAC & Oxygen radical absorption capacity \\
\hline FRAP & Ferric reducing antioxidant power \\
\hline DPPH & 2,2-diphenyl-1-picrylhydrazyl \\
\hline ABTS & 2,2'-azino-bis(3-ethylbenzothiazoline-6-sulfonic acid) \\
\hline UV & Ultraviolet \\
\hline $\mathrm{ACE}$ & Angiotensin-I converter enzyme \\
\hline ROS & Reactive oxygen species \\
\hline HIV & Human immunodeficiency virus \\
\hline HSV & Herpes simplex virus \\
\hline $\mathrm{HPV}$ & Human papilloma virus \\
\hline SARS-CoV & Severe acute respiratory syndrome-coronavirus \\
\hline IL & Interleukin \\
\hline $\mathrm{TNF}-\alpha$ & Tumor necrosis factor- $\alpha$ \\
\hline COX-2 & Cyclooxygenase-2 \\
\hline $\mathrm{NO}$ & Nitric oxide synthase \\
\hline iNOS & Nitric oxide \\
\hline TLR & Toll-like receptors \\
\hline TGF- $\beta$ & Transforming growth factor- $\beta$ \\
\hline NF- $к B$ & Nuclear factor $k b$ \\
\hline MAPK & Mitogen-activated protein kinase \\
\hline LPS & Lipopolysaccharides \\
\hline $\mathrm{MPO}$ & Myeloperoxidase \\
\hline $\mathrm{HO}-2$ & Hemeoxygenase-2 \\
\hline JNK & Jun N-terminal kinase \\
\hline ERK & Extracellular signal-related kinase \\
\hline mTOR & Mammalian target of rapamycin \\
\hline IGF-IR & Insulin-like growth factor-I receptor \\
\hline PI3K & Phosphatidylinositol 3-kinase \\
\hline DPP-IV & Dipeptidyl peptidase-IV \\
\hline GLP-1 & Glucagon-like peptide-1 \\
\hline IRS-I & Insulin receptor substrate-I \\
\hline
\end{tabular}




\section{References}

1. Dawczynski, C.; Schubert, R.; Jahreis, G. Amino acids, fatty acids, and dietary fibre in edible seaweed products. Food Chem. 2007, 103, 891-899. [CrossRef]

2. Gómez-Ordóñez, E.; Jiménez-Escrig, A.; Rupérez, P. Dietary fibre and physicochemical properties of several edible seaweeds from the northwestern Spanish coast. Food Res. Int. 2010, 43, 2289-2294. [CrossRef]

3. Machado, M.; Machado, S.; Pimentel, F.B.; Freitas, V.; Alves, R.C.; Oliveira, M.B.P.P. Amino acid profile and protein quality assessment of macroalgae produced in an integrated multi-trophic aquaculture system. Foods 2020, 9, 1382. [CrossRef]

4. Cermeño, M.; Kleekayai, T.; Amigo-Benavent, M.; Harnedy, P.A.; FitzGerald, R.J. Current knowledge on the extraction, purification, identification, and validation of bioactive peptides from seaweed. Electrophoresis 2020, 41, 1694-1717. [CrossRef] [PubMed]

5. Cherry, P.; O’Hara, C.; Magee, P.J.; McSorley, E.M.; Allsopp, P.J. Risks and benefits of consuming edible seaweeds. Nutr. Rev. 2019, 77, 307-329. [CrossRef]

6. Kazir, M.; Abuhassira, Y.; Robin, A.; Nahor, O.; Luo, J.; Israel, A.; Golberg, A.; Livney, Y.D. Extraction of proteins from two marine macroalgae, Ulva sp. and Gracilaria sp., for food application, and evaluating digestibility, amino acid composition and antioxidant properties of the protein concentrates. Food Hydrocoll. 2019, 87, 194-203. [CrossRef]

7. Paiva, L.; Lima, E.; Patarra, R.F.; Neto, A.I.; Baptista, J. Edible Azorean macroalgae as source of rich nutrients with impact on human health. Food Chem. 2014, 164, 128-135. [CrossRef]

8. Fleurence, J. Seaweed proteins. Trends Food Sci. Technol. 1999, 10, 25-28. [CrossRef]

9. Shuuluka, D.; Bolton, J.J.; Anderson, R.J. Protein content, amino acid composition and nitrogen-to-protein conversion factors of Ulva rigida and Ulva capensis from natural populations and Ulva lactuca from an aquaculture system, in South Africa. J. Appl. Phycol. 2013, 25, 677-685. [CrossRef]

10. Cian, R.E.; Fajardo, M.A.; Alaiz, M.; Vioque, J.; González, R.J.; Drago, S.R. Chemical composition, nutritional and antioxidant properties of the red edible seaweed Porphyra columbina. Int. J. Food Sci. Nutr. 2014, 65, 299-305. [CrossRef]

11. Poojary, M.M.; Orlien, V.; Olsen, K. Conventional and enzyme-assisted green extraction of umami free amino acids from Nordic seaweeds. J. Appl. Phycol. 2019, 31, 3925-3939. [CrossRef]

12. Bocanegra, A.; Macho-González, A.; Garcimartín, A.; Benedí, J.; Sánchez-Muniz, F.J. Whole Alga, Algal Extracts, and Compounds as Ingredients of Functional Foods: Composition and Action Mechanism Relationships in the Prevention and Treatment of Type-2 Diabetes Mellitus. Int. J. Mol. Sci. 2021, 22, 3816. [CrossRef]

13. Harnedy, P.A.; Fitzgerald, R.J. Bioactive proteins, peptides, and amino acids from macroalgae. J. Phycol. 2011, 47, 218-232. [CrossRef]

14. O'Connor, J.; Meaney, S.; Williams, G.A.; Hayes, M. Extraction of protein from four different seaweeds using three different physical pre-treatment strategies. Molecules 2020, 25, 2005. [CrossRef]

15. Biancarosa, I.; Espe, M.; Bruckner, C.G.; Heesch, S.; Liland, N.; Waagbø, R.; Torstensen, B.; Lock, E.J. Amino acid composition, protein content, and nitrogen-to-protein conversion factors of 21 seaweed species from Norwegian waters. J. Appl. Phycol. 2017, 29, 1001-1009. [CrossRef]

16. Taboada, C.; Millan, R.; Miguez, I. Evaluation of marine algae Undaria pinnatifida and Porphyra purpurea as a food supplement: Composition, nutritional value and effect of intake on intestinal, hepatic and renal enzyme activities in rats. J. Sci. Food Agric. 2013, 93, 1863-1868. [CrossRef] [PubMed]

17. Vieira, E.F.; Soares, C.; Machado, S.; Correia, M.; Ramalhosa, M.J.; Oliva-teles, M.T.; Paula Carvalho, A.; Domingues, V.F.; Antunes, F.; Oliveira, T.A.C.; et al. Seaweeds from the Portuguese coast as a source of proteinaceous material: Total and free amino acid composition profile. Food Chem. 2018, 269, 264-275. [CrossRef]

18. Ortiz, J.; Uquiche, E.; Robert, P.; Romero, N.; Quitral, V.; Llantén, C. Functional and nutritional value of the Chilean seaweeds Codium fragile, Gracilaria chilensis and Macrocystis pyrifera. Eur. J. Lipid Sci. Technol. 2009, 111, 320-327. [CrossRef]

19. Ferreira, M.; Teixeira, C.; Abreu, H.; Silva, J.; Costas, B.; Kiron, V.; Valente, L.M.P. Nutritional value, antimicrobial and antioxidant activities of micro- and macroalgae, single or blended, unravel their potential use for aquafeeds. J. Appl. Phycol. 2021, 33, 3507-3518. [CrossRef]

20. Trigueros, E.; Sanz, M.T.; Alonso-Riaño, P.; Beltrán, S.; Ramos, C.; Melgosa, R. Recovery of the protein fraction with high antioxidant activity from red seaweed industrial solid residue after agar extraction by subcritical water treatment. J. Appl. Phycol. 2021, 33, 1181-1194. [CrossRef]

21. Zheng, Y.; Zhang, Y.; San, S. Efficacy of a novel ACE-inhibitory peptide from Sargassum maclurei in hypertension and reduction of intracellular endothelin-1. Nutrients 2020, 12, 653. [CrossRef] [PubMed]

22. Lorenzo, J.M.; Agregán, R.; Munekata, P.; Franco, D.; Carballo, J.; Şahin, S.; Lacomba, R.; Barba, F. Proximate Composition and Nutritional Value of Three Macroalgae: Ascophyllum nodosum, Fucus vesiculosus and Bifurcaria bifurcata. Mar. Drugs 2017, 15, 360. [CrossRef]

23. Echave, J.; Fraga-Corral, M.; Garcia-Perez, P.; Popović-Djordjević, J.; Avdović, E.H.; Radulović, M.; Xiao, J.; Prieto, M.A.; SimalGandara, J. Seaweed Protein Hydrolysates and Bioactive Peptides: Extraction, Purification and Applications. Mar. Drugs 2021, 19, 500. [CrossRef] [PubMed]

24. Torres, P.; Santos, J.P.; Chow, F.; Pena Ferreira, M.J.; dos Santos, D.Y.A.C. Comparative analysis of in vitro antioxidant capacities of mycosporine-like amino acids (MAAs). Algal Res. 2018, 34, 57-67. [CrossRef] 
25. Boonsri, N.; Rudtanatip, T.; Withyachumnarnkul, B.; Wongprasert, K. Protein extract from red seaweed Gracilaria fisheri prevents acute hepatopancreatic necrosis disease (AHPND) infection in shrimp. J. Appl. Phycol. 2017, 29, 1597-1608. [CrossRef]

26. Seca, A.; Pinto, D. Overview on the Antihypertensive and Anti-Obesity Effects of Secondary Metabolites from Seaweeds. Mar. Drugs 2018, 16, 237. [CrossRef]

27. de Queiroz, I.N.L.; Quinderé, A.L.G.; Rodrigues, J.A.G.; de Sousa Oliveira Vanderlei, E.; Ribeiro, N.A.; da Conceição Rivanor, R.L.; Ribeiro, K.A.; Coura, C.O.; Pereira, K.M.A.; Chaves, H.V.; et al. Dual effects of a lectin from the green seaweed Caulerpa cupressoides var. lycopodium on inflammatory mediators in classical models of inflammation. Inflamm. Res. 2015, 64, 971-982. [CrossRef]

28. Lafarga, T.; Acién-Fernández, F.G.; Garcia-Vaquero, M. Bioactive peptides and carbohydrates from seaweed for food applications: Natural occurrence, isolation, purification, and identification. Algal Res. 2020, 48, 101909. [CrossRef]

29. Lee, H.A.; Kim, I.H.; Nam, T.J. Bioactive peptide from Pyropia yezoensis and its anti-inflammatory activities. Int. J. Mol. Med. 2015, 36, 1701-1706. [CrossRef]

30. Conde, E.; Balboa, E.M.; Parada, M.; Falqué, E. Algal proteins, peptides and amino acids. In Functional Ingredients from Algae for Foods and Nutraceuticals; Dominguez, H., Ed.; Woodhead Publishing Elsevier: Cambridge, UK, 2013; pp. 135-180. ISBN 9780857095121.

31. Hayes, M.; Tiwari, B.K. Bioactive carbohydrates and peptides in foods: An overview of sources, downstream processing steps and associated bioactivities. Int. J. Mol. Sci. 2015, 16, 22485-22508. [CrossRef] [PubMed]

32. Charoensiddhi, S.; Conlon, M.A.; Franco, C.M.M.; Zhang, W. The development of seaweed-derived bioactive compounds for use as prebiotics and nutraceuticals using enzyme technologies. Trends Food Sci. Technol. 2017, 70, 20-33. [CrossRef]

33. Yoshiie, T.; Maeda, M.; Kimura, M.; Hama, Y.; Uchida, M.; Kimura, Y. Structural features of N-glycans of seaweed glycoproteins: Predominant occurrence of high-mannose type N-glycans in marine plants. Biosci. Biotechnol. Biochem. 2012, 76, 1996-1998. [CrossRef] [PubMed]

34. Wijesekara, I.; Lang, M.; Marty, C.; Gemin, M.-P.; Boulho, R.; Douzenel, P.; Wickramasinghe, I.; Bedoux, G.; Bourgougnon, N. Different extraction procedures and analysis of protein from Ulva sp. in Brittany, France. J. Appl. Phycol. 2017, 29, $2503-2511$. [CrossRef]

35. Thangam, R.; Senthilkumar, D.; Suresh, V.; Sathuvan, M.; Sivasubramanian, S.; Pazhanichamy, K.; Gorlagunta, P.K.; Kannan, S.; Gunasekaran, P.; Rengasamy, R.; et al. Induction of ROS-Dependent Mitochondria-Mediated Intrinsic Apoptosis in MDA-MB-231 Cells by Glycoprotein from Codium decorticatum. J. Agric. Food Chem. 2014, 62, 3410-3421. [CrossRef]

36. Barre, A.; Simplicien, M.; Benoist, H.; Van Damme, E.J.M.; Rougé, P. Mannose-Specific Lectins from Marine Algae: Diverse Structural Scaffolds Associated to Common Virucidal and Anti-Cancer Properties. Mar. Drugs 2019, 17, 440. [CrossRef]

37. Frenkel, J.; Vyverman, W.; Pohnert, G. Pheromone signaling during sexual reproduction in algae. Plant J. 2014, 79, 632-644. [CrossRef]

38. Damme, E.J.M.; Van Peumans, W.J.; Barre, A.; Rougé, P. Plant Lectins: A Composite of Several Distinct Families of Structurally and Evolutionary Related Proteins with Diverse Biological Roles. CRC Crit. Rev. Plant Sci. 1998, 17, 575-692. [CrossRef]

39. Ambrosio, A.L.; Sanz, L.; Sánchez, E.I.; Wolfenstein-Todel, C.; Calvete, J.J. Isolation of two novel mannan- and L-fucose-binding lectins from the green alga Enteromorpha prolifera: Biochemical characterization of EPL-2. Arch. Biochem. Biophys. 2003, 415, 245-250. [CrossRef]

40. Wu, M.; Tong, C.; Wu, Y.; Liu, S.; Li, W. A novel thyroglobulin-binding lectin from the brown alga Hizikia fusiformis and its antioxidant activities. Food Chem. 2016, 201, 7-13. [CrossRef] [PubMed]

41. Günaydın, G.; Edfeldt, G.; Garber, D.A.; Asghar, M.; Noël-Romas, L.; Burgener, A.; Wählby, C.; Wang, L.; Rohan, L.C.; Guenthner, P.; et al. Impact of Q-Griffithsin anti-HIV microbicide gel in non-human primates: In situ analyses of epithelial and immune cell markers in rectal mucosa. Sci. Rep. 2019, 9, 18120. [CrossRef]

42. Fontenelle, T.P.C.; Lima, G.C.; Mesquita, J.X.; Lopes, J.L.; de Brito, T.V.; Vieira-Júnior, F.C.; Sales, A.B.; Aragão, K.S.; de Souza, M.H.L.P.; Barbosa, A.L.R.; et al. Lectin obtained from the red seaweed Bryothamnion triquetrum: Secondary structure and anti-inflammatory activity in mice. Int. J. Biol. Macromol. 2018, 112, 1122-1130. [CrossRef]

43. Nair, D.; Krishna, J.G.; Panikkar, M.V.N.; Nair, B.G.; Pai, J.G.; Nair, S.S. Identification, purification, biochemical and mass spectrometric characterization of novel phycobiliproteins from a marine red alga, Centroceras clavulatum. Int. J. Biol. Macromol. 2018, 114, 679-691. [CrossRef] [PubMed]

44. Yabuta, Y.; Fujimura, H.; Kwak, C.S.; Enomoto, T.; Watanabe, F. Antioxidant activity of the phycoerythrobilin compound formed from a dried Korean purple laver (Porphyra sp.) during in vitro digestion. Food Sci. Technol. Res. 2010, 16, 347-351. [CrossRef]

45. Chen, X.; Wu, M.; Yang, Q.; Wang, S. Preparation, characterization of food grade phycobiliproteins from Porphyra haitanensis and the application in liposome-meat system. LWT Food Sci. Technol. 2017, 77, 468-474. [CrossRef]

46. Li, W.; Su, H.; Pu, Y.; Chen, J.; Liu, L.; Liu, Q.; Qin, S. Phycobiliproteins: Molecular structure, production, applications, and prospects. Biotechnol. Adv. 2019, 37, 340-353. [CrossRef]

47. Guan, X.; Wang, J.; Zhu, J.; Yao, C.; Liu, J.; Qin, S.; Jiang, P. Photosystem II Photochemistry and Phycobiliprotein of the Red Algae Kappaphycus alvarezii and Their Implications for Light Adaptation. BioMed Res. Int. 2013, 2013, 256549. [CrossRef] [PubMed]

48. Gacesa, R.; Lawrence, K.P.; Georgakopoulos, N.D.; Yabe, K.; Dunlap, W.C.; Barlow, D.J.; Wells, G.; Young, A.R.; Long, P.F. The mycosporine-like amino acids porphyra-334 and shinorine are antioxidants and direct antagonists of Keap1-Nrf2 binding. Biochimie 2018, 154, 35-44. [CrossRef] 
49. Sun, Y.; Zhang, N.; Zhou, J.; Dong, S.; Zhang, X.; Guo, L.; Guo, G. Distribution, Contents, and Types of Mycosporine-Like Amino Acids (MAAs) in Marine Macroalgae and a Database for MAAs Based on These Characteristics. Mar. Drugs 2020, 18, 43. [CrossRef] [PubMed]

50. Cian, R.E.; Martínez-Augustin, O.; Drago, S.R. Bioactive properties of peptides obtained by enzymatic hydrolysis from protein byproducts of Porphyra columbina. Food Res. Int. 2012, 49, 364-372. [CrossRef]

51. Lorenzo, J.M.; Munekata, P.E.S.; Gómez, B.; Barba, F.J.; Mora, L.; Pérez-Santaescolástica, C.; Toldrá, F. Bioactive peptides as natural antioxidants in food products-A review. Trends Food Sci. Technol. 2018, 79, 136-147. [CrossRef]

52. Cao, D.; Lv, X.; Xu, X.; Yu, H.; Sun, X.; Xu, N. Purification and identification of a novel ACE inhibitory peptide from marine alga Gracilariopsis lemaneiformis protein hydrolysate. Eur. Food Res. Technol. 2017, 243, 1829-1837. [CrossRef]

53. Sun, S.; Xu, X.; Sun, X.; Zhang, X.; Chen, X.; Xu, N. Preparation and identification of ACE inhibitory peptides from the marine macroalga Ulva intestinalis. Mar. Drugs 2019, 17, 179. [CrossRef]

54. Admassu, H.; Gasmalla, M.A.A.; Yang, R.; Zhao, W. Identification of Bioactive Peptides with $\alpha$-Amylase Inhibitory Potential from Enzymatic Protein Hydrolysates of Red Seaweed (Porphyra spp). J. Agric. Food Chem. 2018, 66, 4872-4882. [CrossRef] [PubMed]

55. Beaulieu, L.; Sirois, M.; Tamigneaux, É. Evaluation of the in vitro biological activity of protein hydrolysates of the edible red alga, Palmaria palmata (dulse) harvested from the Gaspe coast and cultivated in tanks. J. Appl. Phycol. 2016, 28, 3101-3115. [CrossRef]

56. Indumathi, P.; Mehta, A. A novel anticoagulant peptide from the Nori hydrolysate. J. Funct. Foods 2016, 20, 606-617. [CrossRef]

57. Paiva, L.; Lima, E.; Neto, A.I.I.; Baptista, J. Isolation and characterization of angiotensin I-converting enzyme (ACE) inhibitory peptides from Ulva rigida C. Agardh protein hydrolysate. J. Funct. Foods 2016, 26, 65-76. [CrossRef]

58. Zhang, X.; Cao, D.; Sun, X.; Sun, S.; Xu, N. Preparation and identification of antioxidant peptides from protein hydrolysate of marine alga Gracilariopsis lemaneiformis. J. Appl. Phycol. 2019, 31, 2585-2596. [CrossRef]

59. Furuta, T.; Miyabe, Y.; Yasui, H.; Kinoshita, Y.; Kishimura, H. Angiotensin I Converting Enzyme Inhibitory Peptides Derived from Phycobiliproteins of Dulse Palmaria palmata. Mar. Drugs 2016, 14, 32. [CrossRef]

60. Cermeño, M.; Stack, J.; Tobin, P.R.; O'Keeffe, M.B.; Harnedy, P.A.; Stengel, D.B.; FitzGerald, R.J. Peptide identification from a Porphyra dioica protein hydrolysate with antioxidant, angiotensin converting enzyme and dipeptidyl peptidase IV inhibitory activities. Food Funct. 2019, 10, 3421-3429. [CrossRef]

61. Harnedy, P.A.; O'Keeffe, M.B.; FitzGerald, R.J. Purification and identification of dipeptidyl peptidase (DPP) IV inhibitory peptides from the macroalga Palmaria palmata. Food Chem. 2015, 172, 400-406. [CrossRef]

62. Cian, R.E.; Hernández-Chirlaque, C.; Gámez-Belmonte, R.; Drago, S.R.; Sánchez de Medina, F.; Martínez-Augustin, O. Green alga Ulva spp. hydrolysates and their peptide fractions regulate cytokine production in splenic macrophages and lymphocytes involving the TLR4-NFKB/MAPK pathways. Mar. Drugs 2018, 16, 235. [CrossRef] [PubMed]

63. Reuter, S.; Gupta, S.C.; Chaturvedi, M.M.; Aggarwal, B.B. Oxidative stress, inflammation, and cancer: How are they linked? Free Radic. Biol. Med. 2010, 49, 1603-1616. [CrossRef] [PubMed]

64. Yu, Z.; Yin, Y.; Zhao, W.; Wang, F.; Yu, Y.; Liu, B.; Liu, J.; Chen, F. Characterization of ACE-Inhibitory Peptide Associated with Antioxidant and Anticoagulation Properties. J. Food Sci. 2011, 76, C1149-C1155. [CrossRef]

65. Senthilkumar, D.; Jayanthi, S. Antioxidant activities of purified glycoprotein extracted from Codium decorticatum. J. Appl. Pharm. Sci. 2015, 5, 101-104. [CrossRef]

66. Suh, H.-J.; Lee, H.-W.; Jung, J. Mycosporine Glycine Protects Biological Systems Against Photodynamic Damage by Quenching Singlet Oxygen with a High Efficiency. Photochem. Photobiol. 2003, 78, 109. [CrossRef]

67. Harnedy, P.A.; O'Keeffe, M.B.; FitzGerald, R.J. Fractionation and identification of antioxidant peptides from an enzymatically hydrolysed Palmaria palmata protein isolate. Food Res. Int. 2017, 100, 416-422. [CrossRef]

68. Wen, L.; Tan, S.; Zeng, L.; Wang, Z.; Ke, X.; Zhang, Z.; Tang, H.; Guo, H.; Xia, E. Ultrasound-assisted extraction and in vitro simulated digestion of Porphyra haitanensis proteins exhibiting antioxidative and $\alpha$-glucosidase inhibitory activity. J. Food Meas. Charact. 2020, 14, 3291-3298. [CrossRef]

69. Pimentel, F.B.; Cermeño, M.; Kleekayai, T.; Machado, S.; Rego, A.; Fernandes, E.; Alves, R.C.; Oliveira, M.B.P.P.; FitzGerald, R.J Contribution of in vitro simulated gastrointestinal digestion to the antioxidant activity of Porphyra dioica conchocelis. Algal Res. 2020, 51, 102085. [CrossRef]

70. Pimentel, F.B.; Cermeño, M.; Kleekayai, T.; Harnedy, P.A.; Fernandes, E.; Alves, R.C.; Oliveira, M.B.P.P.; FitzGerald, R.J. Enzymatic Modification of Porphyra dioica-Derived Proteins to Improve their Antioxidant Potential. Molecules 2020, 25, 2838. [CrossRef]

71. Carneiro, R.F.; Duarte, P.L.; Chaves, R.P.; da Silva, S.R.; Feitosa, R.R.; de Sousa, B.L.; Alves, A.W.S.; de Vasconcelos, M.A.; da Rocha, B.A.M.; Teixeira, E.H.; et al. New lectins from Codium isthmocladum Vickers show unique amino acid sequence and antibiofilm effect on pathogenic bacteria. J. Appl. Phycol. 2020, 32, 4263-4276. [CrossRef]

72. Mori, T.; O'Keefe, B.R.; Sowder, R.C.; Bringans, S.; Gardella, R.; Berg, S.; Cochran, P.; Turpin, J.A.; Buckheit, R.W.; McMahon, J.B.; et al. Isolation and characterization of Griffithsin, a novel HIV-inactivating protein, from the red alga Griffithsia sp. J. Biol. Chem. 2005, 280, 9345-9353. [CrossRef] [PubMed]

73. Meuleman, P.; Albecka, A.; Belouzard, S.; Vercauteren, K.; Verhoye, L.; Wychowski, C.; Leroux-Roels, G.; Palmer, K.E.; Dubuisson, J. Griffithsin has antiviral activity against hepatitis C virus. Antimicrob. Agents Chemother. 2011, 55, 5159-5167. [CrossRef] [PubMed]

74. Lusvarghi, S.; Bewley, C.A. Griffithsin: An antiviral lectin with outstanding therapeutic potential. Viruses 2016, 8, 296. [CrossRef] [PubMed] 
75. Derby, N.; Lal, M.; Aravantinou, M.; Kizima, L.; Barnable, P.; Rodriguez, A.; Lai, M.; Wesenberg, A.; Ugaonkar, S.; Levendosky, K.; et al. Griffithsin carrageenan fast dissolving inserts prevent SHIV HSV-2 and HPV infections in vivo. Nat. Commun. 2018, 9, 1-9. [CrossRef]

76. Barre, A.; Damme, E.J.M.V.; Van Simplicien, M.; Benoist, H.; Rougé, P. Man-Specific, GalNAc/T/Tn-Specific and Neu5Ac-Specific Seaweed Lectins as Glycan Probes for the SARS-CoV-2 (COVID-19) Coronavirus. Mar. Drugs 2020, 18, 543. [CrossRef] [PubMed]

77. Barton, C.; Kouokam, J.C.; Hurst, H.; Palmer, K.E. Pharmacokinetics of the antiviral lectin griffithsin administered by different routes indicates multiple potential uses. Viruses 2016, 8, 331. [CrossRef] [PubMed]

78. Micewicz, E.D.; Cole, A.L.; Jung, C.L.; Luong, H.; Phillips, M.L.; Pratikhya, P.; Sharma, S.; Waring, A.J.; Cole, A.M.; Ruchala, P. Grifonin-1: A small HIV-1 entry inhibitor derived from the algal lectin, griffithsin. PLoS ONE 2010, 5, e14360. [CrossRef]

79. Hwang, H.-J.; Han, J.-W.; Jeon, H.; Cho, K.; Kim, J.; Lee, D.-S.; Han, J.W. Characterization of a Novel Mannose-Binding Lectin with Antiviral Activities from Red Alga, Grateloupia chiangii. Biomolecules 2020, 10, 333. [CrossRef]

80. Righini, H.; Francioso, O.; Di Foggia, M.; Quintana, A.M.; Roberti, R. Preliminary Study on the Activity of Phycobiliproteins against Botrytis cinerea. Mar. Drugs 2020, 18, 600. [CrossRef]

81. Beaulieu, L.; Bondu, S.; Doiron, K.; Rioux, L.E.E.; Turgeon, S.L.L. Characterization of antibacterial activity from protein hydrolysates of the macroalga Saccharina longicruris and identification of peptides implied in bioactivity. J. Funct. Foods 2015, 17, 685-697. [CrossRef]

82. O'Keefe, B.R.; Giomarelli, B.; Barnard, D.L.; Shenoy, S.R.; Chan, P.K.S.; McMahon, J.B.; Palmer, K.E.; Barnett, B.W.; Meyerholz, D.K.; Wohlford-Lenane, C.L.; et al. Broad-Spectrum In Vitro Activity and In Vivo Efficacy of the Antiviral Protein Griffithsin against Emerging Viruses of the Family Coronaviridae. J. Virol. 2010, 84, 2511-2521. [CrossRef]

83. Alexandre, K.; Malatji, K.; Mulaudzi, T. Comparison of the antiviral activity of the microbicide candidate griffithsin and its tandemers derivatives against different modes of HIV-1 transmission. Virology 2020, 544, 12-20. [CrossRef]

84. Hirayama, M.; Shibata, H.; Imamura, K.; Sakaguchi, T.; Hori, K. High-Mannose Specific Lectin and Its Recombinants from a Carrageenophyta Kappaphycus alvarezii Represent a Potent Anti-HIV Activity Through High-Affinity Binding to the Viral Envelope Glycoprotein gp120. Mar. Biotechnol. 2016, 18, 144-160. [CrossRef]

85. Hung, L.D.; Hirayama, M.; Ly, B.M.; Hori, K. Biological activity, cDNA cloning and primary structure of lectin KSA-2 from the cultivated red alga Kappaphycus striatum (Schmitz) Doty ex Silva. Phytochem. Lett. 2015, 14, 99-105. [CrossRef]

86. Shin, E.S.; Hwang, H.J.; Kim, I.H.; Nam, T.J. A glycoprotein from Porphyra yezoensis produces anti-inflammatory effects in liposaccharide-stimulated macrophages via the TLR4 signaling pathway. Int. J. Mol. Med. 2011, 28, 809-815. [CrossRef]

87. Mesquita, J.X.; de Brito, T.V.; Fontenelle, T.P.C.; Damasceno, R.O.S.; de Souza, M.H.L.P.; Lopes, J.L.S.; Beltramini, L.M.; Barbosa, A.L.R.; Freitas, A.L.P. Lectin from red algae Amansia multifida Lamouroux: Extraction, characterization and anti-inflammatory activity. Int. J. Biol. Macromol. 2021, 170, 532-539. [CrossRef] [PubMed]

88. Abu Bakar, N.; Anyanji, V.U.; Mustapha, N.M.; Lim, S.L.; Mohamed, S. Seaweed (Eucheuma cottonii) reduced inflammation, mucin synthesis, eosinophil infiltration and MMP-9 expressions in asthma-induced rats compared to Loratadine. J. Funct. Foods 2015, 19, 710-722. [CrossRef]

89. Chaves, R.P.; da Silva, S.R.; do Nascimento-Neto, L.G.; Carneiro, R.F.; da Silva, A.L.C.; Sampaio, A.H.; de Sousa, B.L.; Cabral, M.G.; Videira, P.A.; Teixeira, E.H.; et al. Structural characterization of two isolectins from the marine red alga Solieria filiformis (Kützing) P.W. Gabrielson and their anticancer effect on MCF-7 breast cancer cells. Int. J. Biol. Macromol. 2018, 107, 1320-1329. [CrossRef] [PubMed]

90. Li, P.; Ying, J.; Chang, Q.; Zhu, W.; Yang, G.; Xu, T.; Yi, H.; Pan, R.; Zhang, E.; Zeng, X.; et al. Effects of phycoerythrin from Gracilaria lemaneiformis in proliferation and apoptosis of SW480 cells. Oncol. Rep. 2016, 36, 3536-3544. [CrossRef] [PubMed]

91. Senthilkumar, N.; Kurinjimalar, C.; Thangam, R.; Suresh, V.; Kavitha, G.; Gunasekaran, P.; Rengasamy, R. Further studies and biological activities of macromolecular protein R-Phycoerythrin from Portieria hornemannii. Int. J. Biol. Macromol. 2013, 62, 107-116. [CrossRef]

92. Hayashi, K.; Walde, P.; Miyazaki, T.; Sakayama, K.; Nakamura, A.; Kameda, K.; Masuda, S.; Umakoshi, H.; Kato, K. Active Targeting to Osteosarcoma Cells and Apoptotic Cell Death Induction by the Novel Lectin Eucheuma serra Agglutinin Isolated from a Marine Red Alga. J. Drug Deliv. 2012, 2012, 842785. [CrossRef]

93. do Nascimento-Neto, L.G.; Carneiro, R.F.; da Silva, S.R.; da Silva, B.R.; Arruda, F.V.S.; Carneiro, V.A.; do Nascimento, K.S.; Saker-Sampaio, S.; da Silva, V.A.; Porto, A.L.F.; et al. Characterization of Isoforms of the Lectin Isolated from the Red Algae Bryothamnion seaforthii and Its Pro-Healing Effect. Mar. Drugs 2012, 10, 1936-1954. [CrossRef] [PubMed]

94. Kim, E.-Y.; Kim, Y.-R.; Nam, T.-J.; Kong, I.-S. Antioxidant and DNA protection activities of a glycoprotein isolated from a seaweed, Saccharina japonica. Int. J. Food Sci. Technol. 2012, 47, 1020-1027. [CrossRef]

95. Rafiquzzaman, S.M.; Min Lee, J.; Ahmed, R.; Lee, J.-H.; Kim, J.-M.; Kong, I.-S. Characterisation of the hypoglycaemic activity of glycoprotein purified from the edible brown seaweed, Undaria pinnatifida. Int. J. Food Sci. Technol. 2015, 50, 143-150. [CrossRef]

96. Mu, J.; Hirayama, M.; Sato, Y.; Morimoto, K.; Hori, K. A novel high-mannose specific lectin from the green alga Halimeda renschii exhibits a potent anti-influenza virus activity through high-affinity binding to the viral hemagglutinin. Mar. Drugs 2017, 15, 255. [CrossRef]

97. Sato, Y.; Hirayama, M.; Morimoto, K.; Yamamoto, N.; Okuyama, S.; Hori, K. High mannose-binding lectin with preference for the cluster of $\alpha 1-2$-mannose from the green alga Boodlea coacta is a potent entry inhibitor of HIV-1 and influenza viruses. J. Biol. Chem. 2011, 286, 19446-19458. [CrossRef] 
98. Vanderlei, E.S.O.; Patoilo, K.K.N.R.; Lima, N.A.; Lima, A.P.S.; Rodrigues, J.A.G.; Silva, L.M.C.M.; Lima, M.E.P.; Lima, V.; Benevides, N.M.B. Antinociceptive and anti-inflammatory activities of lectin from the marine green alga Caulerpa cupressoides. Int. Immunopharmacol. 2010, 10, 1113-1118. [CrossRef] [PubMed]

99. Rivanor, R.L.; Chaves, H.V.; Do Val, D.R.; De Freitas, A.R.; Lemos, J.C.; Rodrigues, J.A.G.; Pereira, K.M.A.; De Araújo, I.W.F.; Bezerra, M.M.; Benevides, N.M.B. A lectin from the green seaweed Caulerpa cupressoides reduces mechanical hyper-nociception and inflammation in the rat temporomandibular joint during zymosan-induced arthritis. Int. Immunopharmacol. 2014, $21,34-43$. [CrossRef]

100. Ocaranza, M.P.; Riquelme, J.A.; García, L.; Jalil, J.E.; Chiong, M.; Santos, R.A.S.; Lavandero, S. Counter-regulatory reninangiotensin system in cardiovascular disease. Nat. Rev. Cardiol. 2020, 17, 116-129. [CrossRef]

101. Joel, C.; Sutopo, C.; Prajitno, A.; Su, J.-H.; Hsu, J.-L. Screening of Angiotensin-I Converting Enzyme Inhibitory Peptides Derived from Caulerpa lentillifera. Molecules 2018, 23, 3005. [CrossRef]

102. Wu, Q.; Cai, Q.-F.; Yoshida, A.; Sun, L.-C.; Liu, Y.-X.; Liu, G.-M.; Su, W.-J.; Cao, M.-J. Purification and characterization of two novel angiotensin I-converting enzyme inhibitory peptides derived from R-phycoerythrin of red algae (Bangia fusco-purpurea). Eur. Food Res. Technol. 2017, 243, 779-789. [CrossRef]

103. Fitzgerald, C.; Mora-Soler, L.; Gallagher, E.; O'Connor, P.; Prieto, J.; Soler-Vila, A.; Hayes, M. Isolation and Characterization of Bioactive Pro-Peptides with in Vitro Renin Inhibitory Activities from the Macroalga Palmaria palmata. J. Agric. Food Chem. 2012, 60, 7421-7427. [CrossRef]

104. Fitzgerald, C.; Aluko, R.E.; Hossain, M.; Rai, D.K.; Hayes, M. Potential of a Renin Inhibitory Peptide from the Red Seaweed Palmaria palmata as a Functional Food Ingredient Following Confirmation and Characterization of a Hypotensive Effect in Spontaneously Hypertensive Rats. J. Agric. Food Chem. 2014, 62, 8352-8356. [CrossRef] [PubMed]

105. Sato, M.; Hosokawa, T.; Yamaguchi, T.; Nakano, T.; Muramoto, K.; Kahara, T.; Funayama, K.; Kobayashi, A.; Nakano, T. Angiotensin I-Converting Enzyme Inhibitory Peptides Derived from Wakame (Undaria pinnatifida) and Their Antihypertensive Effect in Spontaneously Hypertensive Rats. J. Agric. Food Chem. 2002, 50, 6245-6252. [CrossRef]

106. Saito, M.; Hosokawa, T.; Yamaguchi, T.; Nakano, T.; Muramoto, K.; Kahara, T.; Funayama, K. Antihypertensive effect of Nori-peptides derived from red alga Porphyra yezoensis in hypertensive patients. Am. J. Hypertens. 2002, 15, A210. [CrossRef]

107. Pimentel, F.B.; Machado, M.; Cermeño, M.; Kleekayai, T.; Machado, S.; Rego, A.M.; Abreu, M.H.; Alves, R.C.; Oliveira, M.B.P.P.; FitzGerald, R.J. Enzyme-Assisted Release of Antioxidant Peptides from Porphyra dioica Conchocelis. Antioxidants 2021, 10, 249. [CrossRef] [PubMed]

108. Park, S.J.; Ryu, J.; Kim, I.H.; Choi, Y.H.; Nam, T.J. Activation of the mTOR signaling pathway in breast cancer MCF-7 cells by a peptide derived from Porphyra yezoensis. Oncol. Rep. 2015, 33, 19-24. [CrossRef]

109. Cian, R.E.; Garzón, A.G.; Ancona, D.B.; Guerrero, L.C.; Drago, S.R. Hydrolyzates from Pyropia columbina seaweed have antiplatelet aggregation, antioxidant and ACE I inhibitory peptides which maintain bioactivity after simulated gastrointestinal digestion. LWT Food Sci. Technol. 2015, 64, 881-888. [CrossRef]

110. Cian, R.E.; López-Posadas, R.; Drago, S.R.; Sánchez de Medina, F.; Martínez-Augustin, O. A Porphyra columbina hydrolysate upregulates IL-10 production in rat macrophages and lymphocytes through an NF- $\mathrm{kB}$, and p38 and JNK dependent mechanism Food Chem. 2012, 134, 1982-1990. [CrossRef]

111. Chen, J.-C.C.; Wang, J.; Zheng, B.-D.D.; Pang, J.; Chen, L.-J.J.; Lin, H.T.; Guo, X. Simultaneous Determination of 8 Small Antihypertensive Peptides with Tyrosine at the C-Terminal in Laminaria japonica Hydrolysates by RP-HPLC Method. J. Food Process. Preserv. 2016, 40, 492-501. [CrossRef]

112. Suetsuna, K.; Maekawa, K.; Chen, J.-R. Antihypertensive effects of Undaria pinnatifida (wakame) peptide on blood pressure in spontaneously hypertensive rats. J. Nutr. Biochem. 2004, 15, 267-272. [CrossRef]

113. Feng, X.; Liao, D.; Sun, L.; Wu, S.; Lan, P.; Wang, Z.; Li, C.; Zhou, Q.; Lu, Y.; Lan, X. Affinity Purification of Angiotensin Converting Enzyme Inhibitory Peptides from Wakame (Undaria Pinnatifida) Using Immobilized ACE on Magnetic Metal Organic Frameworks. Mar. Drugs 2021, 19, 177. [CrossRef]

114. Garcia-Vaquero, M.; Mora, L.; Hayes, M. In Vitro and In Silico Approaches to Generating and Identifying Angiotensin-Converting Enzyme I Inhibitory Peptides from Green Macroalga Ulva lactuca. Mar. Drugs 2019, 17, 204. [CrossRef]

115. Pan, S.; Wang, S.; Jing, L.; Yao, D. Purification and characterisation of a novel angiotensin-I converting enzyme (ACE)-inhibitory peptide derived from the enzymatic hydrolysate of Enteromorpha clathrata protein. Food Chem. 2016, 211, 423-430. [CrossRef]

116. Crusz, S.M.; Balkwill, F.R. Inflammation and cancer: Advances and new agents. Nat. Rev. Clin. Oncol. 2015, 12, 584-596. [CrossRef] [PubMed]

117. Grivennikov, S.I.; Greten, F.R.; Karin, M. Immunity, Inflammation, and Cancer. Cell 2010, 140, 883-899. [CrossRef] [PubMed]

118. Tornatore, L.; Thotakura, A.K.; Bennett, J.; Moretti, M.; Franzoso, G. The nuclear factor kappa B signaling pathway: Integrating metabolism with inflammation. Trends Cell Biol. 2012, 22, 557-566. [CrossRef] [PubMed]

119. Chen, C.Y.; Kao, C.L.; Liu, C.M. The cancer prevention, anti-inflammatory and anti-oxidation of bioactive phytochemicals targeting the TLR4 signaling pathway. Int. J. Mol. Sci. 2018, 19, 2729. [CrossRef]

120. Garcia-Oliveira, P.; Otero, P.; Pereira, A.G.; Chamorro, F.; Carpena, M.; Echave, J.; Fraga-Corral, M.; Simal-Gandara, J.; Prieto, M.A. Status and Challenges of Plant-Anticancer Compounds in Cancer Treatment. Pharmaceuticals 2021, 14, 157. [CrossRef]

121. Athukorala, Y.; Trang, S.; Kwok, C.; Yuan, Y. Antiproliferative and Antioxidant Activities and Mycosporine-Like Amino Acid Profiles of Wild-Harvested and Cultivated Edible Canadian Marine Red Macroalgae. Molecules 2016, 21, 119. [CrossRef] 
122. Park, S.J.; Ryu, J.; Kim, I.H.; Choi, Y.H.; Nam, T.J. Induction of apoptosis by a peptide from Porphyra yezoensis: Regulation of the insulin-like growth factor I receptor signaling pathway in MCF-7 cells. Int. J. Oncol. 2014, 45, 1011-1016. [CrossRef]

123. Mennella, I.; Fogliano, V.; Vitaglione, P. Salivary lipase and $\alpha$-amylase activities are higher in overweight than in normal weight subjects: Influences on dietary behavior. Food Res. Int. 2014, 66, 463-468. [CrossRef]

124. Opinto, G.; Natalicchio, A.; Marchetti, P. Physiology of incretins and loss of incretin effect in type 2 diabetes and obesity. Arch. Physiol. Biochem. 2013, 119, 170-178. [CrossRef]

125. Stack, J.; Tobin, P.R.; Gietl, A.; Harnedy, P.A.; Stengel, D.B.; FitzGerald, R.J. Seasonal variation in nitrogenous components and bioactivity of protein hydrolysates from Porphyra dioica. J. Appl. Phycol. 2017, 29, 2439-2450. [CrossRef]

126. Harnedy, P.A.; FitzGerald, R.J. In vitro assessment of the cardioprotective, anti-diabetic and antioxidant potential of Palmaria palmata protein hydrolysates. J. Appl. Phycol. 2013, 25, 1793-1803. [CrossRef]

127. Lee, M.K.; Kim, I.H.; Choi, Y.H.; Choi, J.W.; Kim, Y.M.; Nam, T.J. The proliferative effects of Pyropia yezoensis peptide on IEC-6 cells are mediated through the epidermal growth factor receptor signaling pathway. Int. J. Mol. Med. 2015, 35, 909-914. [CrossRef] [PubMed]

128. McLaughlin, C.M.; Sharkey, S.J.; Harnedy, P.A.; Parthsarathy, V.; Allsopp, P.J.; McSorley, E.M.; FitzGerald, R.J.; O’Harte, F.P.M. Twice daily oral administration of Palmaria palmata protein hydrolysate reduces food intake in streptozotocin induced diabetic mice, improving glycaemic control and lipid profiles. J. Funct. Foods 2020, 73, 104101. [CrossRef]

129. McLaughlin, C.M.; Harnedy, P.A.; Lafferty, R.A.; Sharkey, S.; Parthsarathy, V.; Allsopp, P.J.; McSorley, E.M.; FitzGerald, R.J.; O'Harte, F.P.M. Macroalgal protein hydrolysates from Palmaria palmata influence the 'incretin effect' in vitro via DPP-4 inhibition and upregulation of insulin, GLP-1 and GIP secretion. Eur. J. Nutr. 2021, 60, 4439-4452. [CrossRef]

130. Cian, R.E.; Salgado, P.R.; Drago, S.R.; González, R.J.; Mauri, A.N. Development of naturally activated edible films with antioxidant properties prepared from red seaweed Porphyra columbina biopolymers. Food Chem. 2014, 146, 6-14. [CrossRef]

131. Ryu, J.; Park, S.J.; Kim, I.H.; Choi, Y.H.; Nam, T.J. Protective effect of porphyra-334 on UVA-induced photoaging in human skin fibroblasts. Int. J. Mol. Med. 2014, 34, 796-803. [CrossRef]

132. Corrochano, A.R.; Ferraretto, A.; Arranz, E.; Stuknytė, M.; Bottani, M.; O’Connor, P.M.; Kelly, P.M.; De Noni, I.; Buckin, V.; Giblin L. Bovine whey peptides transit the intestinal barrier to reduce oxidative stress in muscle cells. Food Chem. 2019, 288, 306-314. [CrossRef] [PubMed]

133. Sawada, Y.; Sakamoto, Y.; Toh, M.; Ohara, N.; Hatanaka, Y.; Naka, A.; Kishimoto, Y.; Kondo, K.; Iida, K. Milk-derived peptide Val-Pro-Pro (VPP) inhibits obesity-induced adipose inflammation via an angiotensin-converting enzyme (ACE) dependent cascade. Mol. Nutr. Food Res. 2015, 59, 2502-2510. [CrossRef] [PubMed]

134. Lee, M.K.; Kim, I.H.; Choi, Y.H.; Nam, T.J. A peptide from Porphyra yezoensis stimulates the proliferation of IEC 6 cells by activating the Insulin-like growth factor I receptor signaling pathway. Int. J. Mol. Med. 2015, 35, 533-538. [CrossRef] [PubMed] 